University of Nebraska - Lincoln

DigitalCommons@University of Nebraska - Lincoln

USGS Staff -- Published Research

US Geological Survey

2000

Natural and Anthropogenic Influences on the Distribution of the Threatened Neosho Madtom in a Midwestern Warmwater Stream

Mark L. Wildhaber

U.S. Geological Survey (USGS)

Vernon M. Tabor

US fish and wildlife Service

Daniel W. Mulhern

U.S. Fish and Wildlife Service, Manhattan, Kansas

Kenneth L. Powell

Westwood Professional Services, Inc

Scott P. Sowa

University of Missouri

Follow this and additional works at: http://digitalcommons.unl.edu/usgsstaffpub

Part of the Geology Commons, Oceanography and Atmospheric Sciences and Meteorology Commons, Other Earth Sciences Commons, and the Other Environmental Sciences Commons

Wildhaber, Mark L.; Tabor, Vernon M.; Mulhern, Daniel W.; Powell, Kenneth L.; and Sowa, Scott P., "Natural and Anthropogenic Influences on the Distribution of the Threatened Neosho Madtom in a Midwestern Warmwater Stream" (2000). USGS Staff -Published Research. 943.

http:// digitalcommons.unl.edu/usgsstaffpub/943

This Article is brought to you for free and open access by the US Geological Survey at DigitalCommons@University of Nebraska - Lincoln. It has been accepted for inclusion in USGS Staff -- Published Research by an authorized administrator of DigitalCommons@University of Nebraska - Lincoln. 


\title{
Natural and Anthropogenic Influences on the Distribution of the Threatened Neosho Madtom in a Midwestern Warmwater Stream
}

\author{
Mark L. Wildhaber, ${ }^{*}$ Ann L. Allert, and Christopher J. Schmitt \\ U.S. Geological Survey, Columbia Environmental Research Center, \\ 4200 New Haven Road, Columbia, Missouri 65201, USA
}

VERnON M. TABor and Daniel MUlhern

U.S. Fish and Wildlife Service,

315 Houston Street, Suite E, Manhattan, Kansas 66502, USA

KenNeth L. Powell

Westwood Professional Services, Inc., 7599 Anagram Drive, Eden Prairie, Minnesota 55344, USA

\section{ScotT P. SowA}

Missouri Cooperative Fish and Wildlife Research Unit, The School of Natural Resources, University of Missouri, 302 ABNR Building, Columbia, Missouri 65211, USA

\begin{abstract}
We attempted to discern the contributions of physical habitat, water chemistry, nutrients, and contaminants from historic lead-zinc mining activities on the riffle-dwelling benthic fish community of the Spring River, a midwestern warmwater stream that originates in Missouri and flows into Kansas and Oklahoma. The Spring River has a fish community that includes the Neosho madtom Noturus placidus, a species federally listed as threatened. Although anthropogenic factors such as contaminants limited populations and densities of fishes, an integrated assessment of natural and anthropogenic factors was necessary to effectively estimate the influence of the latter. Fish populations in the Spring River, especially Neosho madtoms, seem to be limited by the presence of cadmium, lead, and zinc in water and in benthic invertebrate food sources and by physical habitat. The population density and community structure of fish in the Spring River also seem to be related to water chemistry and nutrients. Concurrently, diminished food availability may be limiting fish populations at some sites where Neosho madtoms are not found. Many of the natural factors that may be limiting Neosho madtom and other riffle-dwelling fish populations in the Spring River probably are characteristic of the physiographic region drained by the upper reach and many of the tributaries of the Spring River. Our results indicate that competition between the Neosho madtom and other species within the riffle-dwelling fish community is an unlikely cause of Neosho madtom population limitation in the Spring River.
\end{abstract}

Relationships between stream fish communities and their habitats have been well documented (Angermeier and Karr 1984; Matthews and Heins 1987; Kessler and Thorp 1993). Physical habitat complexity has been correlated with fish species diversity (Gorman and Karr 1978). Habitat factors such as water depth, velocity, and substrate composition are important to stream fishes (Aadland 1993). Moreover, habitat utilization by stream fishes varies with community composition (Fausch and White 1981; Finger 1982), and water chemistry and nutrients affect the distribution and abun-

* Corresponding author: mark_wildhaber@usgs.gov

Received March 19, 1998; accepted May 14, 1999 dance of stream fishes (Layher and Maughan 1985; Layher et al. 1987; Maret et al. 1997). Habitat has been the primary focus of studies that target factors limiting the distribution and density of stream fishes, especially threatened and endangered fishes (Kessler and Thorp 1993; Freeman and Freeman 1994).

The Neosho madtom Noturus placidus is a small ( $<75 \mathrm{~mm}$ total length) ictalurid first described as a species in 1969 (Taylor 1969). Neosho madtoms have been found in the highest numbers in riffles during daylight in late summer and early fall, after young of the year are estimated to have recruited to the population (Moss 1983; Luttrell et al. 1992; Fuselier and Edds 1994). Neosho madtoms prefer the interstitial spaces of unconsolidated pebbles 


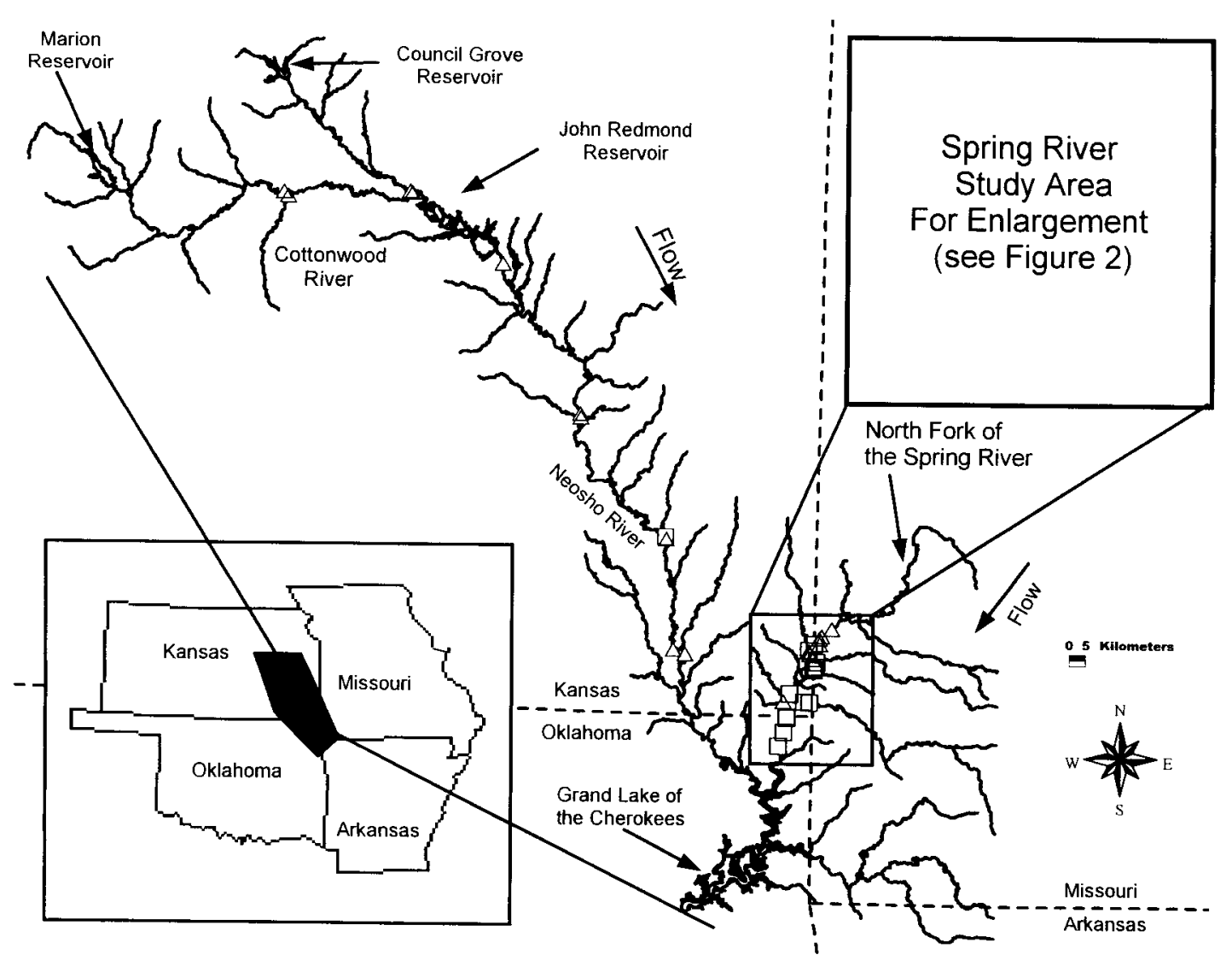

Figure 1.-Sampling sites on the Neosho, Cottonwood, and Spring rivers in 1994. Triangles represent sites where Neosho madtoms were collected; squares represent sites where they were not collected.

and gravel, moderate to slow flows, and depths averaging $0.23 \mathrm{~m}$ (Moss 1983). Neosho madtoms feed on larval insects among stones at night (Cross and Collins 1995). The Neosho madtom was listed as threatened by the U.S. Fish and Wildlife Service (USFWS) in May 1990, and a recovery plan was approved in September 1991 (USFWS 1991). The USFWS (1991) hypothesized that habitat and potential fish competitors of the Neosho madtom, such as other ictalurids, darters (Percidae), and other riffle-dwelling benthic fishes, may limit Neosho madtom populations. Currently, Neosho madtoms are found in main stems of the Neosho, Cottonwood, and Spring rivers in Kansas, Missouri, and Oklahoma (Luttrell et al. 1992; Cross and Collins 1995; Wilkinson et al. 1996) (Figure 1). The density of Neosho madtoms is much greater in the Neosho system (i.e., the Neosho and Cottonwood rivers combined) than in the Spring River (Moss 1983; Wilkinson et al. 1996). Cross and Collins (1995) described the Spring River drainage as supporting 20 fishes not found anywhere else in Kansas. Except for one small population just upstream of Baxter Springs, Kansas (Pflieger 1975; Barks 1977; Wilkinson et al. 1996), Neosho madtoms have only been collected from the Spring River upstream of the primary sources of pollution from lead $(\mathrm{Pb})$ and zinc $(\mathrm{Zn})$ mining (Figure 2).

Studies of the effects of contaminants on fish populations have generally focused on the contaminants (McCormick et al. 1994) and given little attention to other concurrent factors (Neves and Angermeier 1990; Hall et al. 1996; Scott and Hall 1997). Hall et al. (1996) assessed habitat factors along with contaminants; however, they emphasized overall ecological health and biological integrity of the fish community, not specific populations of fish. Contaminants and physicochemical characteristics differ between the Neosho and Cottonwood rivers (Neosho system) and the Spring River (Moss 1983; Spruill 1987; Allen and Blackford 1995). All are affected by similar anthropo- 


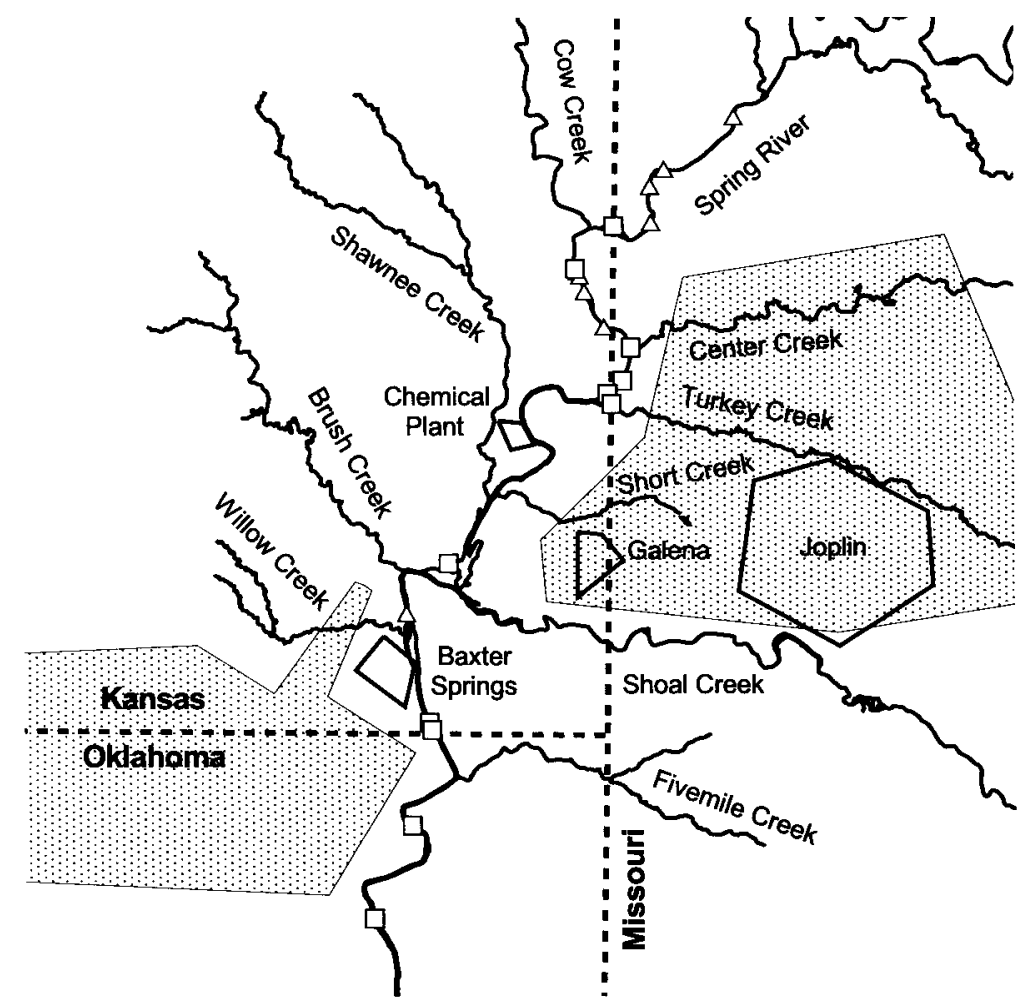

FIGURE 2.-Enlargement of the Spring River study area with sampling sites in 1994. Triangles represent sites where Neosho madtoms were collected; squares represent sites where they were not collected. Lead-zinc mining and processing occurred within shaded areas.

genic factors (agricultural runoff and municipal waste inputs) (Allen and Blackford 1995; Kiner et al. 1997). The Spring River is also impacted by runoff from historic $\mathrm{Pb}-\mathrm{Zn}$ mining and related $\mathrm{ac}-$ tivities that have resulted in elevated levels of $\mathrm{Pb}$, Zn, and cadmium (Cd) (Barks 1977; Czarneski 1985; Spruill 1987; Smith 1988; Schmitt et al. 1993 ) and by industrial inputs from chemical manufacturing and industrial facilities (Kiner et al. 1997). Lead, Zn, Cd, arsenic (As), iron (Fe), mercury $(\mathrm{Hg})$, and manganese $(\mathrm{Mn})$ are also a concern in the Neosho system. However, concentrations of $\mathrm{Pb}$ and $\mathrm{Zn}$ in fish and sediments of the Neosho system are much lower than those historically found in Center and Turkey creeks, tributaries of the Spring River. Further, $\mathrm{As}, \mathrm{Fe}, \mathrm{Hg}$, and $\mathrm{Mn}$ have relatively low concentrations in the Neosho system (Spruill 1987; Smith 1988; Schmitt et al. 1993; Allen and Blackford 1995). Most of the metals of concern in the Neosho and Spring River systems can be toxic to fish, and water quality standards for protection of aquatic life have been established for them (USEPA 1986); therefore, they must be considered in any comprehensive evaluation of these river systems. Previous studies (Moss 1983) indicate the Spring River tends to be less turbid and has lower un-ionized ammonia $\left(\mathrm{NH}_{3}\right)$, chloride (Cl), and sulfate $\left(\mathrm{SO}_{4}\right)$ concentrations than the $\mathrm{Ne}$ osho system. Turbidity may provide protection to the Neosho madtom from predators; $\mathrm{NH}_{3}, \mathrm{Cl}$, and $\mathrm{SO}_{4}$ may have both natural and anthropogenic sources (Wetzel 1983).

Detrimental effects of $\mathrm{Pb}, \mathrm{Zn}$, and $\mathrm{Cd}$ on fish have been well documented, and all three can be acutely toxic (USEPA 1986; Eisler 1988). Effects have been documented for waterborne (Eisler and Hennekey 1977; Weber 1993; Bryan et al. 1995) and dietary exposures (Thomas and Juedes 1992; Woodward et al. 1994). Lead affects heme synthesis (Johansson-Sjobeck and Larsson 1979), respiration (Somero et al. 1977), and reproductive behavior (Weber 1993) of fishes. High concentrations of $\mathrm{Zn}$ cause hyperglycemia (Wagner and McKeown 1982), behavioral avoidance (Woodward et al. 1995, 1997), increased heterozygosity of specific allozymes (Roark and Brown 1996), 
and reduced survival (Eisler and Hennekey 1977). Cadmium can affect the immune system (LemaireGony et al. 1995), the kidney (Gill et al. 1989), and behavior (Bryan et al. 1995).

The primary objective of this paper is to evaluate natural and anthropogenic factors that may be limiting the Neosho madtom and other riffledwelling benthic fishes in the Spring River. We wanted to determine if lower densities of Neosho madtoms in the Spring River than in the Neosho system were a result of metals contamination, lower-quality physicochemical habitat, biotic interactions, or some combination of these factors.

\section{Study Area}

The study area included the main stems of the Neosho (Grand) and Cottonwood rivers in Kansas and Oklahoma and the Spring River in Kansas, Missouri, and Oklahoma (Figures 1, 2). All are part of the Arkansas River system. Part or all of the main stems of these rivers are in the Prairie Parkland Province (Bailey 1995) and the Central Irregular Plains (Omernik 1987). The Neosho system and the lower Spring River drain mainly mixed-grass prairie with mature riparian vegetation along some sections, whereas the upper Spring River and many of its tributaries primarily drain deciduous forests of the Ozark Uplands Province ecoregion (Moss 1983). The Spring River and its tributaries drain parts of the Tri-State Mining District in Missouri, Kansas, and Oklahoma (Spruill 1987), which was mined for $\mathrm{Pb}$ and $\mathrm{Zn}$ from 1850 to the 1960s (Barks 1977). The Spring River drains approximately half the land area, has $70 \%$ of the mean annual discharge and 1.7 times the gradient of the Neosho system; however, all three rivers in this study possess similar riffle-pool habitat (Moss 1983; Kiner et al. 1997). The Cottonwood and Neosho rivers join near Emporia, Kansas; the Neosho and Spring rivers join near Miami, Oklahoma, in what is now Grand Lake of the Cherokees (Figure 1). The Cottonwood River, Neosho River upstream of its confluence with the Cottonwood River, and Spring River are fifth-order streams. Downstream of its confluence with the Cottonwood, the Neosho River is a sixth-order stream. The Neosho and Cottonwood rivers are regulated by reservoirs. The Spring River is essentially unregulated until its confluence with Shoal Creek in Cherokee County, Kansas, in a power plant cooling reservoir.

\section{Methods}

We quantified Neosho madtom distribution, Neosho madtom habitat, and the benthic communities associated with Neosho madtoms in the Neosho system to compare them with those in the miningaffected Spring River. We collected data on the aquatic community (fish and invertebrate species richness and density of potential competitors), physical habitat (depth, velocity, and substrate size), water chemistry (temperature, turbidity, $\mathrm{pH}$, dissolved oxygen, hardness, alkalinity, conductivity, $\mathrm{SO}_{4}$, and $\mathrm{Cl}$ ) nutrients (un-ionized $\mathrm{NH}_{3}$, nitrite plus nitrate $\left[\mathrm{NO}_{2}+\mathrm{NO}_{3}\right]$, and phosphate $\left[\mathrm{PO}_{4}\right]$ ), and metals and metalloids (As, $\mathrm{Cd}, \mathrm{Fe}, \mathrm{Hg}, \mathrm{Mn}$, $\mathrm{Pb}$, and $\mathrm{Zn}$ ) in water, invertebrates, or both. This list of measurements was compiled from what other researchers had previously identified as factors of concern in the Neosho and Spring River systems, as discussed in the introduction (e.g., Barks 1977; Spruill 1987; Smith 1988; Allen and Blackford 1995; Kiner et al. 1997). We used an empirical model based on physical habitat, water chemistry, and nutrients measured in the Neosho system during 1991 to predict the Neosho madtom distribution for that system and Spring River in 1994 without information on metals or metalloids. We then compared predicted and observed values from both river systems and different years to assess the extent to which basic environmental quality and metals contamination limited Neosho madtom distribution in the Spring River. We also used the 1994 data to compare the Neosho system to the Spring River and to compare sites on the Spring River with Neosho madtoms (madtom sites) to sites on the Spring River without Neosho madtoms (nomadtom sites). We compared differences in habitat and benthic communities between the Neosho system and the Spring River relative to differences in madtom versus no-madtom sites within the Spring River in an attempt to separate system differences from within-Spring River differences.

The methods we used to model the Neosho system are supported by the work of others (Layher and Maughan 1985; Leftwich et al. 1997). Based on previous research (Moss 1983; USFWS 1991; Luttrell et al. 1992; Fuselier and Edds 1994), we assumed that the abundance of Neosho madtoms on gravel bars during daylight in late summerearly autumn is an index of their overall abundance at a site. The discrete nature of the summer-fall distribution of the Neosho madtom and its comparatively specialized habitat requirements facilitated investigation and habitat modeling. Layher and Maughan (1985) stated that habitat models are generally more successful for species with narrow niche requirements than for generalists, and that they are better applied within than across ecore- 
gions. Because the lower Spring River represents an ecotone, the model we developed should be effective.

We selected sites on the Neosho, Cottonwood, and Spring rivers that maximized the probability of collecting Neosho madtoms. In the Neosho system, 12 shoreline gravel bars comprising stones generally less than $38-\mathrm{mm}$ diameter and known to harbor Neosho madtoms were selected by the USFWS for monitoring Neosho madtom populations (USFWS 1991). All 12 sites on the Neosho and Cottonwood rivers were sampled in 1991. Eleven sites, many the same sites sampled in 1991, were again sampled in 1994. In the Spring River, 20 gravel bars between the North Fork confluence and Grand Lake of the Cherokees (most of the bars in the river) were selected. In 1991 and 1994, sampling at all sites occurred during daylight between August and October.

At each 1991 site, three to five transects perpendicular to the river channel were spaced equally from downstream to upstream along the length of the gravel bar. In most instances, five stations were spaced equally but at least $2 \mathrm{~m}$ apart along each transect. Fewer than five stations were established when the river channel was less than $10 \mathrm{~m}$ wide or when a station would be too deep to seine $(>1.25 \mathrm{~m})$. Transects on each gravel bar were sampled in order from downstream to upstream. On each transect, stations were sampled in order of their distance from the gravel bar. To minimize impacts of samples on each other, sampling proceeded in the following order at each station: fishes, substrate, water depth, water velocity, and surface water. Fishes were collected from a $4.5-\mathrm{m}^{2}$ area by disturbing the gravel substrate. We started $3 \mathrm{~m}$ upstream of a stationary seine $\left(3.0-\mathrm{mm}^{2} \mathrm{mesh}\right)$ and proceeded downstream to the seine. All ictalurids, including Neosho madtoms, were identified (Pflieger 1975) and released back into the river. Substrate was collected from an undisturbed area adjacent to the fish sampling location with a 13$\mathrm{cm}$-deep $\times 10-\mathrm{cm}$-diameter cylindrical grab sampler. The substrate sample was sieved and categorized into five size-classes $(<2 \mathrm{~mm}, 2$ to $<9$ $\mathrm{mm}, 9$ to $<19 \mathrm{~mm}, 19$ to $<38 \mathrm{~mm}$, and $\geq 38 \mathrm{~mm}$ ), which were then weighed. Water depth and water velocity at $60 \%$ of water depth were measured with a Marsh-McBirney model 201 current meter. After all station samples were collected at a site, a single surface water grab sample was collected and analyzed with a Hach model DREL/1C portable colorimeter for $\mathrm{pH}$, alkalinity, hardness, conductivity, turbidity, $\mathrm{NH}_{3}, \mathrm{NO}_{2}+\mathrm{NO}_{3}, \mathrm{SO}_{4}, \mathrm{PO}_{4}$, and $\mathrm{Cl}$.
In 1994, the 1991 sampling procedures were repeated except that pore waters and benthic invertebrates also were collected, and these samples along with surface water samples were analyzed for metals. Access to certain sites was limited and we obtained complete data for only 6 of the 11 Neosho system sites. At each station, sampling proceeded in the following order to minimize impacts of samples on each other: fishes, benthic invertebrates, substrate, pore water, water depth, and water velocity. As in 1991, all ictalurids were identified in the field and released. Voucher specimens of other taxa and unidentifiable fishes were preserved in ethanol for later identification. Benthic invertebrates were collected in undisturbed substrate adjacent to the fished area with a modified Hess sampler $\left(0.1-\right.$ or $0.037-\mathrm{m}^{2}$ bottom area; the smaller one was used for water depths generally shallower than $0.19 \mathrm{~m}$ ) with a $0.3-\mathrm{mm}$-mesh collection bag. Substrate within the Hess sampler was disturbed for $2 \mathrm{~min}$. Benthic invertebrates were preserved in $80 \%$ ethanol for later identification to the lowest taxonomic level possible (Merritt and Cummins 1984) except chironomids and oligochaetes were not identified below the family level. Pore water was extracted directly from undisturbed substrate with a vacuum pump system upstream of the Hess sample collection site and adjacent to the fish collection site. A Hydrolab Surveyer II was used to measure temperature, dissolved oxygen, $\mathrm{pH}$, and conductivity during pore-water extraction. Pore-water samples were composited by transect for subsequent analyses. Each composite sample was distributed between two acid-cleaned, highdensity polyethylene bottles. One subsample was analyzed by inductively coupled argon plasma transmission spectroscopy (ICAP) for As, Cd, Fe, $\mathrm{Hg}, \mathrm{Mn}, \mathrm{Pb}$, and $\mathrm{Zn}$. The second subsample was analyzed for alkalinity, hardness, and $\mathrm{Cl}$ by titration; for turbidity with a Hach $2100 \mathrm{~A}$ turbidimeter; for $\mathrm{NH}_{3}$ with an Orion EA940 meter; and for $\mathrm{NO}_{2}$ $+\mathrm{NO}_{3}, \mathrm{SO}_{4}$, and $\mathrm{PO}_{4}$ with a Hach DR 2000 spectrophotometer (APHA et al. 1992). All pore-water sampling equipment was acid-cleaned between sites. Water velocity at $60 \%$ of water depth was measured with a Swoffer Instruments model 2100 current meter.

In 1994, after all station samples were collected at a site, we collected surface water and benthic invertebrate samples for metals analyses and measured geospatial coordinates. A surface water grab sample was collected from the midpoint of the center transect for analysis of metals and water chemistry. Because pore water was extracted on 
TABLE 1.-Riffle-dwelling fish taxa collected in the Neosho, Cottonwood, and Spring rivers that were assumed to be benthic competitors of the Neosho madtom based on habitat use and feeding descriptions as given by Pflieger (1975).

\begin{tabular}{|c|c|}
\hline Family and scientific name & Common name \\
\hline \multicolumn{2}{|l|}{ Catostomidae } \\
\hline Cycleptus elongatus & Blue sucker \\
\hline Hypentelium nigricans & Northem hog sucker \\
\hline Moxostoma duquesnei & Black redhorse \\
\hline Moxostoma erythrurum & Golden redhorse \\
\hline $\begin{array}{l}\text { Moxostoma macrolepidotum } \\
\text { Moxostoma spp. }\end{array}$ & Shorthead redhorse \\
\hline \multicolumn{2}{|l|}{ Sciaenidae } \\
\hline Aplodinotus grunniens & Freshwater drum \\
\hline \multicolumn{2}{|l|}{ Cyprinidae } \\
\hline Erimystax $x$-punctatus & Gravel chub \\
\hline \multicolumn{2}{|c|}{ Notropis spp. or Pimephales spp. } \\
\hline Phenacobius mirabilis & Suckermouth minnow \\
\hline Pimephales notatus & Bluntnose minnow \\
\hline Pimephales tenellus & Slim minnow \\
\hline Pimephales vigilax & Bullhead minnow \\
\hline \multicolumn{2}{|l|}{ Ictaluridae } \\
\hline Ictalurus punctatus & Channel catfish \\
\hline Noturus exilis & Slender madtom \\
\hline Noturus flavus & Stonecat \\
\hline Noturus miurus & Brindled madtom \\
\hline Noturus nocturnus & Freckled madtom \\
\hline Pylodictis olivaris & Flathead catfish \\
\hline \multicolumn{2}{|l|}{ Cottidae } \\
\hline Cottus carolinae & Banded sculpin \\
\hline \multicolumn{2}{|l|}{ Percidae } \\
\hline Etheostoma blennioides & Greenside darter \\
\hline Etheostoma flabellare & Fantail darter \\
\hline Etheostoma nigrum & Johnny darter \\
\hline Etheostoma stigmaeum & Speckled darter \\
\hline Etheostoma spectabile & Orangethroat darter \\
\hline Etheostoma whipplei & Redfin darter \\
\hline Etheostoma zonale & Banded darter \\
\hline Percina caprodes & Logperch \\
\hline Percina copelandi & Channel darter \\
\hline Percina phoxocephala & Slenderhead darter \\
\hline Percina shumardi & River darter \\
\hline
\end{tabular}

gravel bars from the same interstitial spaces where Neosho madtoms are found and because surface water and pore-water measurements were similar (see Wildhaber et al. 1996), only pore-water concentrations are presented here. However, surface water measurements were incorporated into estimates of Neosho madtom densities because no pore-water measurements were collected in 1991. Benthic invertebrates for metals analyses were collected from seines used for fish sampling, augmented with kick-net collections when necessary. Invertebrates were placed in acid-washed plastic bags with acid-cleaned, Teflon-coated forceps. They were analyzed by ICAP for the same metals as pore waters except $\mathrm{As}$ and $\mathrm{Hg}$ were not analyzed. For metals, benthic invertebrate samples were partitioned into "Decapoda" (crayfish),
"Megaloptera" (dobsonflies), and "others" (generally molluscs). Although Neosho madtoms would not eat adults of these large taxa, these taxa were selected to represent concentrations of toxic metals in detritivorous and predatory invertebrates upon which they do feed. Benthic invertebrate samples of less than $5 \mathrm{~g}$ were analyzed for metals without partitioning. Geospatial coordinates of the gravel bar were determined with a Trimble Pathfinder Plus geographical positioning system.

\section{Statistical Analyses}

We analyzed the data at the site level to assess differences between the Neosho system and the Spring River and between madtom and no-madtom sites in the Spring River. Arithmetic site means were calculated for depth, velocity, and pore-water chemistry and metals. For each metal, we included only samples with concentrations above the detection limit in the mean because we considered these samples a measure of the maximum possible exposure at a site. For benthic invertebrates, we calculated species richness and Ephemeroptera, Plecoptera, and Trichoptera richness (EPT) at each site. Previous studies have demonstrated the effectiveness of these metrics for documenting environmental impacts (Kerans and Karr 1994). We calculated site densities of Neosho madtoms and, as a group, potential competitors (Table 1). We calculated fish densities by dividing the total number of Neosho madtoms or potential competitors collected at a site by the total area sampled with the kick seine. We determined the list of potential competitors based on habitat preferences and food habits of each species, as described by Pflieger (1975). For each site, we calculated species richness as a general measure of the natural and anthropogenic impacts on the fish community. Because species richness values depend highly on the level of effort (sampling time, area, or both), we also calculated species rarefaction, which adjusts species richness estimates to a constant level of effort (Hurlbert 1971; James and Rathbun 1981), as suggested by Ludwig and Reynolds (1988):

$$
E(S)=\sum_{i=1}^{S}\left[1-\frac{\left(\frac{n-n_{i}}{N}\right)}{\left(\frac{n}{N}\right)}\right]
$$

$E(S)=$ expected number of species;

$n=$ total number of fish collected;

$\boldsymbol{n}_{\boldsymbol{i}}=$ total number of fish collected in species $i$;

$N=$ sample size;

$S=$ total number of species collected. 
We used rarefaction to calculate expected number of species at a site $[E(S)]$ when a given number of fish $(N)$ are collected. The number of stations per site sampled for fish ranged from 10 to 25 , so we used species rarefaction to make species richness comparable among sites. Comparable species richness values among sites were produced by using the same sample size $(N)$ for each site in all rarefaction calculations. The sample size $(N)$ used in all rarefaction calculations was the lowest number of fish collected at any one site. We did not calculate any similarity indices; these were reported by Schmitt et al. (1997).

For substrate, we calculated size category means at each site by dividing total weight of a size category by total weight of all size categories. We also calculated the substrate geometric mean and fredle index (geometric mean adjusted for distribution of particle sizes) at each site, as suggested by McMahon et al. (1996), to characterize substrate suitability for Neosho madtoms. The fredle index relates potential permeability of sediment to water and hence is an indirect index of dissolved oxygen transport within sediment, and it has been correlated with the emergence success of salmonid alevins (Platts et al. 1983, citing other sources). Composite site means for metal concentrations in benthic invertebrates were calculated by summing the product of metal concentration $(\mu \mathrm{g} / \mathrm{g})$ and biomass of a taxonomic category $(\mathrm{g})$ over all taxonomic categories and dividing the sum by the total biomass of all taxonomic categories combined (g).

We first checked site means for normality and then tested homogeneity of variance for river system differences using Levene's test, as recommended by Milliken and Johnson (1984). In 1994, the number of madtom and no-madtom sites in the Spring River were almost equal (9 and 11 sites, respectively). Therefore, for tests between madtom and no-madtom sites, we assumed that $F$-statistics and $t$ tests for comparisons of normally distributed variables would be effective whether or not variances were equal, as suggested by Milliken and Johnson (1984). Any variable with nonnormal site means was $\log _{10}$-transformed. The absence of Neosho madtoms (density $=0$ ) at 11 of 20 sites in the Spring River in 1994 made it impossible to normalize densities through transformation even with the addition of a constant before transformation. Thus, for 1994 data, we restricted correlation and regression analyses to madtom sites, which precluded development of multiple-regression models.

Stepwise multiple linear regression and Krus-
kal-Wallis tests were used to compare observed and predicted densities of Neosho madtoms from the Spring River in 1994 based on observed densities of Neosho madtoms from the Neosho system in 1991 (SAS Institute 1990). Stepwise multiple linear regression with forward selection was used to develop a model based on physical habitat, water chemistry, and nutrient measures from 1991 Neosho system data. The variable list used included depth, water velocity, substrate size categories, geometric mean of substrate size, fredle index, and surface water chemistry. Inclusion of individual variables in the model was based on an $\alpha=0.15$ criterion and a final model in which all variables were significant at $\alpha=0.05$. The model based on the 1991 data were used to estimate $\mathrm{Ne}$ osho madtoms densities at sites sampled in 1994. Kruskal-Wallis tests were used to validate the USFWS 1991 model from 1994 Neosho system data and to assess distributional differences between observed and predicted 1994 Neosho madtom densities in the Spring River upstream and downstream of Center Creek (i.e., most upstream source of mining-derived contaminants).

The statistical methods used to make primary comparisons within 1994 data included analysis of variance (ANOVA), correlation analysis, multivariate ANOVA (MANOVA), principal components analysis (PCA), and discriminant analysis (SAS Institute 1990). Separate one-way ANOVAs were performed on site means for each variable between river systems and between madtom and no-madtom sites. Along with testing the composite metal concentration for benthic invertebrates, we tested if either of the major groups, Decapoda and Megaloptera, biased our composite results. We tested for differences in metal concentration between Decapoda and Megaloptera at sites where both groups were represented. We also tested for significant differences between river systems and between madtom and no-madtom sites for Decapoda and Megaloptera concentrations separately. Because $\log _{10}$-transformation of $\mathrm{NO}_{2}+\mathrm{NO}_{3}$ porewater concentrations did not produce equal variances between river systems, $\mathrm{NO}_{2}+\mathrm{NO}_{3}$ concentrations were analyzed with a Welch (1951) variance-weighted ANOVA. Correlation analyses were used to assess relationships between nonzero Neosho madtom densities and other variables. We used the multivariate tests to verify the results of the individual ANOVA tests and to determine if the significant differences identified by ANOVA effectively characterized river system and madtom-no-madtom differences. In our discriminant 


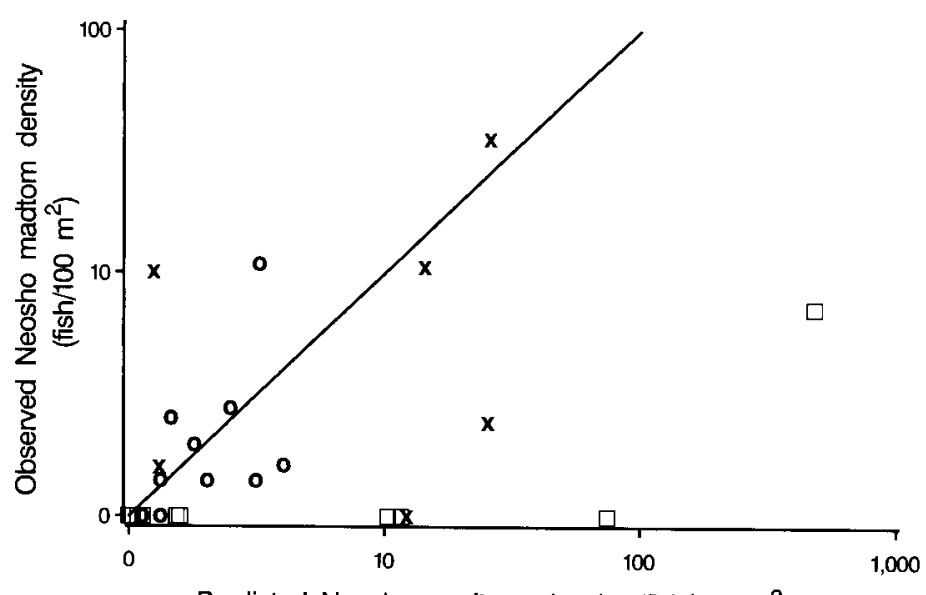

Predicted Neosho madtom density (fish/100 $\mathrm{m}^{2}$ )

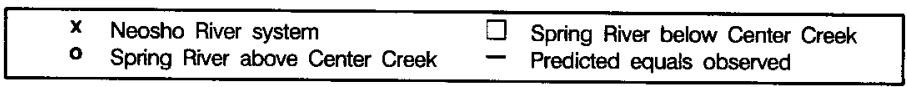

Figure 3.--Predicted versus observed Neosho madtoms densities in Neosho and Spring river systems. Predicted values are based on a regression model developed from 1991 USFWS data. Observed values were obtained during 1994 collections. Observed densities of the Neosho and Cottonwood rivers combined (Neosho system) were significantly higher than densities found the Spring River below Center Creek $(P=0.0007 ; N=21$; all comparisons here are from Kruskal-Wallis tests), whereas predicted values did not differ between river systems $(P=0.28 ; N$ $=16$ ). Observed and predicted Neosho madtom densities in the Neosho system were not significantly different for observed and predicted densities, respectively, at Spring River sites above Center Creek $(P=0.057, N=21$; $P=0.19, N=16$ ). Observed Neosho madtom densities at Spring River sites above Center Creek were significantly higher than densities at sites below Center Creek $(P=0.008 ; N=20)$, whereas predicted values were not $(P=$ $0.94 ; N=20$ ).

analyses, we used stepwise discriminant analyses with forward selection followed by removal to produce a discriminant function. We then tested how well the resulting discriminant function described the observed data.

Because we were required to have more observations than variables before we did any multivariate analyses, we shortened the list of variables used for MANOVA, PCA, and discriminant analysis in three ways. First, we excluded from multivariate analyses any metal that was detected at fewer than $75 \%$ of our sites. Second, we used the fredle index to represent all substrate categories. Third, we used only variables with $P$-values less than 0.05 in one-way ANOVAs.

\section{Results}

\section{Predicted Neosho Madtom Densities}

Stepwise regression with forward selection of 1991 USFWS data from the Neosho system produced the following equation for predicting $\mathrm{Ne}$ osho madtom densities from physical habitat, water chemistry, and nutrient measurements:

$$
D=10^{-1.447-0.892 \cdot \log _{10}(G 38)-0.0897 \cdot \mathrm{Cl}}
$$

$$
\begin{aligned}
D= & \text { density of Neosho madtoms (number/ } \\
& \left.100 \mathrm{~m}^{2}\right) ; \\
G 38= & \text { weight proportion of substraten } \geq 38 \\
& \text { mm; } \\
\mathrm{Cl}= & \text { chloride ion concentration }(\mathrm{mg} / \mathrm{L}) .
\end{aligned}
$$

For the equation, $r^{2}=0.72 ; N=11 ; P<0.017$ for $G 3$; and $P<0.0026$ for Cl. Based on a Bonferroni-adjusted $\alpha=0.0025(0.05 / 20$ comparisons), $\mathrm{Cl}$ was highly correlated with $\mathrm{SO}_{4}(r=0.89$; $P=0.0003 ; N=11)$, conductivity $(r=0.83 ; P$ $=0.0015 ; N=11)$, and hardness $(r=0.82 ; P=$ $0.0022 ; N=11$ ). As a result of these strong correlations, only $\mathrm{Cl}$ significantly added to the variance in the 1991 data that was accounted for by the overall regression model.

At the six 1994 sites where water quality and substrate composition were measured in the $\mathrm{Ne}$ osho system, predicted Neosho madtom densities ranged from $12.1 / 100 \mathrm{~m}^{2}$ less to $42.6 / 100 \mathrm{~m}^{2}$ more than observed densities (Figure 3). Despite the wide range, observed and predicted 1994 densities for the Neosho system were not significantly different (Kruskal-Wallis test for distributional differences: $P=0.92$; df $=1$ ). Likewise, predicted 
and observed densities of Neosho madtoms at Spring River sites above Center Creek did not differ significantly. Below Center Creek, however, observed densities were markedly lower than predicted. Of the combined 26 sites on the Neosho, Cottonwood, and Spring rivers, the Spring River sites at the mouth of Center Creek and downstream at Willow Creek were predicted to have the two highest densities of Neosho madtoms. The observed average density of Neosho madtoms was $100 \%$ of the predicted average density above Center Creek but only $1 \%$ of prediction below Center Creek. Above Center Creek, the predicted average density of Neosho madtoms was $13 \%$ of that predicted for the Neosho system, whereas below Center Creek the average predicted density was $364 \%$ of the density predicted for the Neosho system.

\section{Neosho System versus Spring River}

Fishes and invertebrates.-The aquatic communities of the Neosho system and Spring River differed, as illustrated by fish densities and by fish and invertebrate community composition (Table 2). Nonzero Neosho madtom densities were higher in the Neosho system than in the Spring River (Table 2). Furthermore, Neosho madtoms were collected at only 9 of 20 sites in the Spring River as opposed to 10 of 11 sites in the Neosho system. Density of potential competitors was also greater in the Neosho system than in the Spring River. In contrast, fish species rarefaction was greater in the Spring River than in the Neosho system. Neither species richness of fish and benthic invertebrates nor EPT differed between river systems (Table 2).

Physical habitat, water chemistry, and nutrients.-The Neosho system and Spring River differ in their physical habitat, water chemistry, and nutrient concentrations. Most of the substrate measurements and indices indicate that Spring River substrate consists of coarser gravel than that of the Neosho system (Table 2). Pore waters of the Neosho system were warmer, harder, had higher $\mathrm{NH}_{3}$ and $\mathrm{SO}_{4}$ concentrations, and were more conductive, alkaline, and turbid than those of the Spring River (Table 2). Pore waters from all sites except those on the Cottonwood River were typically alkaline (pH 7.5-8.5, alkalinity $100-160 \mathrm{mg} / \mathrm{L}$ ) and hard $(150-220 \mathrm{mg} / \mathrm{L})$; the Cottonwood River was particularly high in alkalinity (about $200 \mathrm{mg} / \mathrm{L}$ ) and very hard (>330 mg/L) (Schmitt et al. 1997). No doubt reflecting the dissolution of naturally occurring gypsum in central Kansas (Spruill 1987), pore-water concentrations of sulfate were more than twofold greater in the Cottonwood River
(132-145 mg/L) than in the Neosho River (49-58 $\mathrm{mg} / \mathrm{L}$ ) and more than threefold greater than in reaches of the Spring River and its tributaries not affected by mining (Schmitt et al. 1997). In contrast, $\mathrm{NO}_{2}+\mathrm{NO}_{3}$ concentrations were greater in the Spring River than the Neosho system (Table 2). Depth, velocity, substrate 9 to $<19 \mathrm{~mm}$, and pore-water $\mathrm{pH}$, dissolved oxygen, $\mathrm{PO}_{4}$, and $\mathrm{Cl}$ did not differ between river systems (Table 2).

Metals.-Concentrations of various metals in pore waters and benthic invertebrates differed significantly between the Neosho system and Spring River. Concentrations of $\mathrm{Fe}$ and $\mathrm{Mn}$ in pore water were higher in the Neosho system, Cd was only detected in Spring River pore waters at the mouth of Turkey Creek, and $\mathrm{Pb}$ was not detected in any pore-water sample (Table 2). Concentrations of Cd and $\mathrm{Pb}$ were higher in composite samples of benthic invertebrates from the Spring River than in those from the Neosho system (Table 2). Detectable concentrations of $\mathrm{As}, \mathrm{Hg}$, and $\mathrm{Zn}$ in pore waters and of $\mathrm{Fe}$ and $\mathrm{Zn}$ in composite invertebrate samples did not differ significantly between river systems (Table 2).

Except for a few inconsistencies among composite, Decapoda, and Megaloptera metal concentrations, taxonomic group analyses generally supported the results of river system comparisons based on composite samples (Table 2). Concentrations of $\mathrm{Fe}$ and $\mathrm{Mn}$ were significantly higher in Megaloptera than in Decapoda (respectively: $F=$ 62.57 and 9.86; $P=0.0001$ and $0.0032 ; N=42$ ). Concentrations of $\mathrm{Cd}$ in Decapoda were not quite significantly different between river systems. Lead was detected in the Neosho system at only one site for Decapoda and at no sites for Megaloptera. Concentrations of $\mathrm{Zn}$ in Megaloptera were greater in the Spring River than in the Neosho system

Physical habitat, water chemistry, nutrients, and metals combined.-The shortened list of variables used in multivariate analyses included pore-water temperature, conductivity, turbidity, alkalinity, and hardness; $\mathrm{NH}_{3}, \mathrm{NO}_{2}+\mathrm{NO}_{3}, \mathrm{SO}_{4}$, and $\mathrm{Mn}$ pore-water concentrations; the fredle index; and $\mathrm{Cd}, \mathrm{Mn}$, and $\mathrm{Zn}$ concentrations in composite invertebrate samples. Results of MANOVA demonstrated a significant difference between river systems (Wilks' lambda: $P<0.002 ; N=22$ ). Principal components analysis of the same variables accounted for more than $63 \%$ of the variability in the data with only the first two principal components (Figure 4); the first component effectively separated Neosho system sites from Spring River sites. Based on the same 22 sites used in MAN- 
TABLE 2.- Means and one-way analysis of variance test results ( $P$-values) for comparisons between the Neosho River system and Spring River and between Spring River sites with and without Neosho madtoms. Abbreviations used are: $\mathrm{ND}=$ none detected; $\mathrm{NA}=$ not applicable; $\mathrm{DL}=$ detection limit or detection limit range

\begin{tabular}{|c|c|c|c|c|c|c|c|}
\hline \multirow[b]{2}{*}{ Measurement } & & \multicolumn{4}{|c|}{ Within-Spring River comparisons } \\
\hline & $\begin{array}{c}\text { Bet } \\
\text { Neosho } \\
\text { system: } \\
\text { mean }(N)\end{array}$ & $\begin{array}{l}\text { Spring } \\
\text { River: } \\
\text { mean }(N)\end{array}$ & $\begin{array}{c}P \text {-value } \\
(F)\end{array}$ & $\begin{array}{l}\text { Neosho } \\
\text { madtoms } \\
\text { present: } \\
\text { mean }(N)\end{array}$ & $\begin{array}{c}\text { Neosho } \\
\text { madtoms } \\
\text { absent: } \\
\text { mean }(N)\end{array}$ & \multicolumn{2}{|c|}{$\begin{array}{c}P \text {-value } \\
(F)\end{array}$} \\
\hline \multicolumn{8}{|c|}{ Community } \\
\hline Neosho madtom density (per $100 \mathrm{~m}^{2}$ ) & $12.00(10)$ & $3.26(9)$ & $0.042 \quad(4.83)$ & $3.26(9)$ & (11) & NA & \\
\hline $\begin{array}{l}\text { Density of potential benthic fish } \\
\text { competitors (per } 100 \mathrm{~m}^{2} \text { ) }\end{array}$ & $301.94(11)$ & $120.89(20)$ & $0.0045(9.46)$ & $195.49(9)$ & $81.59(11)$ & 0.0094 & $4(8.46)$ \\
\hline Fish species rarefaction & $6.18(11)$ & $8.10(20)$ & $0.0053(9.08)$ & $8.11(9)$ & $8.09(11)$ & 0.98 & $(0.00)$ \\
\hline Fish species richness & $16.64(11)$ & $16.35(20)$ & $0.88 \quad(0.02)$ & $19.22(9)$ & $14.00(11)$ & 0.05 & $(4.42)$ \\
\hline Invertebrate taxa richness & 28.2 & $33.15(20)$ & $0.17 \quad(2.05)$ & $37.00(9)$ & $30.00(11)$ & 0.021 & $(6.46)$ \\
\hline $\begin{array}{l}\text { Emphemeroptera, Plecoptera, } \\
\text { Tricoptera (EPT) richness }\end{array}$ & $18.40(5)$ & $17.65(20)$ & $0.78 \quad(0.08)$ & $21.33(9)$ & $14.64(11)$ & 0.0038 & $3(11.02)$ \\
\hline \multicolumn{8}{|c|}{ Habitat } \\
\hline Water depth (m) & $0.33(11)$ & $0.35(20)$ & $0.56 \quad(0.35)$ & $0.37(9)$ & $0.39(11)$ & 0.54 & $(0.40)$ \\
\hline Velocity at $60 \%$ of depth $(\mathrm{m} / \mathrm{s})$ & $0.44(11)$ & $0.47(20)$ & $0.56 \quad(0.35)$ & $0.44(9)$ & $0.50(11)$ & 0.28 & $(1.23)$ \\
\hline Pore-water temperature $\left({ }^{\circ} \mathrm{C}\right)$ & $25.84(6)$ & $22.05(20)$ & $0.012(7.40)$ & $20.56(9)$ & $23.26(11)$ & 0.055 & $(4.23)$ \\
\hline Pore-water turbidity (nephelometric & & & & & & & \\
\hline $\begin{array}{l}\text { units) } \\
\text { Substrate } \geq 38 \mathrm{~mm} \text { (weight } \%)\end{array}$ & $\begin{array}{r}254.90(6) \\
12.64(6)\end{array}$ & $\begin{array}{l}59.27(20) \\
25.72(20)\end{array}$ & $\begin{array}{l}0.0007(15.21) \\
0.026(5.64)\end{array}$ & $\begin{array}{l}86.83(9) \\
22.05(9)\end{array}$ & $\begin{array}{l}43.37(11) \\
28.72(11)\end{array}$ & $\begin{array}{l}0.044 \\
0.25\end{array}$ & $\begin{array}{l}(4.79) \\
(1.42)\end{array}$ \\
\hline Substrate $<38$ to $\geq 19 \mathrm{~mm}$ (weight $\%$ ) & $26.67(6)$ & $35.24(20)$ & $0.030 \quad(5.35)$ & $36.85(9)$ & $33.93(11)$ & 0.46 & $(0.56)$ \\
\hline Substrate $<19$ to $\geq 9 \mathrm{~mm}$ (weight $\%$ ) & $23.71(6)$ & $17.66(20)$ & $0.052(4.27)$ & $19.10(9)$ & $16.48(11)$ & 0.30 & (1.13) \\
\hline Substrate $<9$ to $\geq 2 \mathrm{~mm}$ (weight $\%$ ) & $23.08(6)$ & $14.52(20)$ & $0.0085(8.21)$ & $14.56(9)$ & $14.49(11)$ & 0.98 & $(0.00)$ \\
\hline Substrate $<2 \mathrm{~mm}$ (weight $\%$ ) & $13.90(6)$ & $6.86(20)$ & $0.0009(14.49)$ & $7.44(9)$ & $6.39(11)$ & 0.57 & $(0.34)$ \\
\hline Substrate geometric mean & $11.74(6)$ & $20.83(20)$ & $0.0034(10.58)$ & $19.34(9)$ & $22.05(11)$ & 0.38 & $(0.81)$ \\
\hline Fredle index & $5.96(6)$ & $10.56(20)$ & $0.0079(8.39)$ & $10.09(9)$ & $10.96(11)$ & 0.71 & $(0.15)$ \\
\hline \multicolumn{8}{|c|}{ Pore-water chemistry } \\
\hline $\mathrm{pH}$ & $7.85(6)$ & $7.84(20)$ & $0.97 \quad(0.00)$ & $7.77(9)$ & $7.90(11)$ & 0.35 & $(0.93)$ \\
\hline Dissolved oxygen (mg/L) & $8.36(6)$ & $7.36(20)$ & $0.064 \quad(3.77)$ & $7.86(9)$ & $6.95(11)$ & 0.093 & (3.15) \\
\hline Conductivity $(\mu \mathrm{mhos} / \mathrm{cm})$ & $0.56(6)$ & $0.40(20)$ & $0.0019(12.15)$ & $0.39(9)$ & $0.41(11)$ & 0.53 & $(0.40)$ \\
\hline Alkalinity $(\mathrm{mg} / \mathrm{L})$ & $165.61(6)$ & $135.90(20)$ & $0.0008(14.78)$ & $142.93(9)$ & $130.15(11)$ & 0.0092 & $2(8.51)$ \\
\hline Hardness (mg/L) & $230.04(6)$ & $169.36(20)$ & $0.0005(15.89)$ & $170.94(9)$ & $168.07(11)$ & 0.70 & $(0.16)$ \\
\hline Un-ionized $\mathrm{NH}_{3}(\mathrm{mg} / \mathrm{L})$ & $0.12(6)$ & $0.04(20)$ & $0.0001(29.89)$ & $0.06(9)$ & $0.04(11)$ & 0.0053 & $3(10.03)$ \\
\hline $\mathrm{NO}_{2}+\mathrm{NO}_{3}(\mathrm{mg} / \mathrm{L})$ & $0.22(6)$ & $1.47(20)$ & $0.0006(15.44)$ & $1.33(9)$ & $1.59(11)$ & 0.46 & $(0.57)$ \\
\hline $\mathrm{SO}_{4}(\mathrm{mg} / \mathrm{L})$ & $72.80(6)$ & $31.80(20)$ & $0.0007(15.11)$ & $26.71(9)$ & $36.68(11)$ & 0.11 & $(2.90)$ \\
\hline $\mathrm{PO}_{4}(\mathrm{mg} / \mathrm{L})$ & $0.23(6)$ & $0.34(20)$ & $0.074 \quad(3.49)$ & $0.34(9)$ & $0.35(11)$ & 0.91 & $(0.10)$ \\
\hline $\mathrm{Cl}(\mathrm{mg} / \mathrm{L})$ & $16.20(6)$ & $16.39(20)$ & $0.94 \quad(0.01)$ & $17.63(9)$ & $15.45(11)$ & 0.32 & $(1.04)$ \\
\hline \multicolumn{8}{|c|}{ Pore-water metals $(\mu \mathrm{g} / \mathrm{L})$} \\
\hline As $(D L=12.3)$ & $20.60(2)$ & $16.38(4)$ & $0.24 \quad(1.94)$ & $13.40(2)$ & $19.35(2)$ & 0.11 & $(7.64)$ \\
\hline $\mathrm{Cd}(\mathrm{DL}=0.59)$ & ND & $0.73(1)$ & NA & ND & $0.73(1)$ & $\mathrm{NA}$ & \\
\hline $\mathrm{Fe}(\mathrm{DL}=6.52)$ & $75.97(4)$ & $16.78(7)$ & $0.0045(14.15)$ & $13.93(4)$ & $21.50(3)$ & 0.32 & $(1.22)$ \\
\hline $\mathrm{Hg}(\mathrm{DL}=0.10)$ & $0.22(3)$ & $0.11(2)$ & $0.35 \quad(1.23)$ & $0.11(1)$ & $0.10(1)$ & NA & \\
\hline $\mathrm{Mn}(\mathrm{DL}=0.06)$ & $83.21(6)$ & $32.55(20)$ & $0.041 \quad(4.65)$ & $40.11(9)$ & $27.43(11)$ & 0.34 & $(0.96)$ \\
\hline $\mathrm{Pb}(\mathrm{DL}=4.12)$ & ND & ND & NA & ND & ND & NA & \\
\hline $\mathrm{Zn}(\mathrm{DL}=10.9)$ & $44.54(6)$ & $55.34(20)$ & $0.27 \quad(1.30)$ & $47.72(9)$ & $62.47(11)$ & 0.26 & $(1.33)$ \\
\hline \multicolumn{8}{|c|}{ Benthic invertebrate metals $(\mu \mathrm{g} / \mathrm{g})$} \\
\hline $\mathrm{Cd}(\mathrm{DL}=0.038-0.27)$ & & & & & & & \\
\hline Composite & $0.10(6)$ & $0.23(16)$ & (6.34) & $0.14(6)$ & $0.32(10)$ & 0.021 & $(6.80)$ \\
\hline Decapoda & $0.10(4)$ & $0.23(12)$ & $0.079 \quad(3.60)$ & $0.12(5)$ & $0.43(7)$ & 0.016 & $(8.48)$ \\
\hline Megaloptera & $0.07(4)$ & $0.24(13)$ & $0.019 \quad(6.92)$ & $0.11(4)$ & $0.33(9)$ & 0.042 & $(5.30)$ \\
\hline \multicolumn{8}{|l|}{$\mathrm{Fe}(\mathrm{DL}=3.81-27.02)$} \\
\hline Composite & $153.91(6)$ & $147.37(20)$ & $(0.03)$ & $147.17(9)$ & $147.54(11)$ & 0.99 & $(0.00)$ \\
\hline Decapoda & $99.59(5)$ & $102.69(18)$ & $0.87 \quad(0.03)$ & $119.71(9)$ & $88.10(9)$ & 0.092 & $(3.21)$ \\
\hline Megaloptera & $198.97(4)$ & $272.30(15)$ & $0.16 \quad(2.14)$ & $296.99(6)$ & $256.98(9)$ & 0.53 & $(0.42)$ \\
\hline \multicolumn{8}{|l|}{$\operatorname{Mn}(\mathrm{DL}=0.15-1.08)$} \\
\hline Composite & $47.73(6)$ & $115.39(20)$ & $0.0021(11.83)$ & $130.31(9)$ & $104.47(11)$ & 0.40 & $(0.74)$ \\
\hline
\end{tabular}


TABLE 2.-Continued.

\begin{tabular}{|c|c|c|c|c|c|c|c|}
\hline \multirow[b]{2}{*}{ Measurement } & \multicolumn{3}{|c|}{ Between-river comparisons } & \multicolumn{4}{|c|}{ Within-Spring River comparisons } \\
\hline & $\begin{array}{c}\text { Neosho } \\
\text { system: } \\
\text { mean }(N)\end{array}$ & $\begin{array}{c}\text { Spring } \\
\text { River: } \\
\text { mean }(N)\end{array}$ & $\begin{array}{c}P \text {-value } \\
(F)\end{array}$ & $\begin{array}{c}\text { Neosho } \\
\text { madtoms } \\
\text { present: } \\
\text { mean }(N)\end{array}$ & $\begin{array}{c}\text { Neosho } \\
\text { madtoms } \\
\text { absent: } \\
\text { mean }(N)\end{array}$ & \multicolumn{2}{|c|}{$\begin{array}{c}P \text {-value } \\
(F)\end{array}$} \\
\hline Decapoda & $40.19(5)$ & $94.10(18)$ & $0.0085(8.43)$ & $110.89(9)$ & $79.85(9)$ & 0.29 & $(1.22)$ \\
\hline Megaloptera & $54.51(4)$ & $207.01(15)$ & $0.0003(20.25)$ & $241.55(6)$ & $186.81(9)$ & 0.42 & $(0.70)$ \\
\hline \multicolumn{8}{|l|}{$\mathrm{Pb}(\mathrm{DL}=0.38-2.70)$} \\
\hline Composite & $0.73(2)$ & $2.01(15)$ & $0.021 \quad(6.61)$ & $1.58(6)$ & $2.36(9)$ & 0.17 & $(2.15)$ \\
\hline Decapoda & $0.68(1)$ & $1.90(8)$ & $0.15 \quad(2.56)$ & $1.46(2)$ & $2.07(6)$ & 0.53 & $(0.45)$ \\
\hline Megaloptera & ND & $2.71(10)$ & NA & $1.01(2)$ & $3.48(8)$ & 0.11 & $(3.26)$ \\
\hline \multicolumn{8}{|l|}{$\mathrm{Zn}(\mathrm{DL}=0.76-5.40)$} \\
\hline Composite & $27.64(6)$ & $40.14(20)$ & $0.18 \quad(1.92)$ & $26.64(9)$ & $56.13(11)$ & 0.005 & (10.24) \\
\hline Decapoda & $27.43(5)$ & $36.02(18)$ & $0.32 \quad(1.05)$ & $27.35(9)$ & $47.47(9)$ & 0.032 & $(5.54)$ \\
\hline Megaloptera & $24.24(4)$ & $55.34(15)$ & $0.023 \quad(6.23)$ & $32.64(6)$ & $78.65(9)$ & 0.0043 & (11.87) \\
\hline
\end{tabular}

OVA, stepwise discriminant analysis produced a list of four significant variables: pore-water alkalinity, $\mathrm{NH}_{3}, \mathrm{SO}_{4}$, and temperature. The resulting discriminant function successfully categorized by river system the 26 sites at which all variables were measured ( $0 \%$ error rate).

\section{Neosho Madtom versus No-Neosho Madtom Sites in the Spring River}

Fish and invertebrates.-The following metrics were significantly greater at Spring River madtom sites than at no-madtom sites: potential competitors, fish species richness, benthic invertebrate taxa richness, and EPT (Table 2). Fish rarefaction did not differ between madtom and no-madtom sites (Table 2).

Physical habitat, water chemistry, and nutrients.-Water chemistry and nutrient measurements revealed a few differences between madtom and no-madtom sites, and no differences in physical habitat were evident. Madtom sites had higher $\mathrm{NH}_{3}$, alkalinity, and turbidity than no-madtom sites (Table 2), but depth, water velocity, all substrate size categories, temperature, $\mathrm{pH}$, dissolved oxygen, conductivity, hardness, $\mathrm{NO}_{2}+\mathrm{NO}_{3}, \mathrm{SO}_{4}$, $\mathrm{PO}_{4}$, and $\mathrm{Cl}$ in pore water did not differ significantly between madtom and no-madtom sites.

Metals.-Only concentrations of metals in benthic invertebrates differed between madtom and no-madtom sites. Cadmium and $\mathrm{Zn}$ concentrations in benthic invertebrates were higher at no-madtom sites than at madtom sites, whereas detectable concentrations of $\mathrm{Fe}, \mathrm{Mn}$, and $\mathrm{Pb}$ in benthic invertebrates did not differ significantly between madtom and no-madtom sites (Table 2). As with the be- tween-river systems analyses, concentrations of $\mathrm{Fe}$ and Mn were significantly higher in Megaloptera than in Decapoda (respectively, $F=57.60$ and $11.98 ; P=0.0001$ and $0.0019 ; N=28$ ). Separate analyses of invertebrate taxonomic groups produced the same results as the composite analysis and thus supported use of the composite analyses. As noted earlier, $\mathrm{Cd}$ in pore water was only detected at the mouth of Turkey Creek, where no madtoms were collected. Detectable concentrations of pore-water $\mathrm{As}, \mathrm{Fe}, \mathrm{Hg}, \mathrm{Mn}$, and $\mathrm{Zn}$ were not significantly different between madtom and no-madtom sites. Although its concentrations did not differ significantly between madtom and nomadtom sites, $\mathrm{Zn}$ in pore water was elevated at the mouths of Center Creek $(116 \mu \mathrm{g} / \mathrm{L})$ and Turkey Creek (369 $\mu \mathrm{g} / \mathrm{L})$ (Schmitt et al. 1997).

Physical habitat, water chemistry, nutrients, and metals combined.-The shortened list of variables used in multivariate analyses included pore-water turbidity, alkalinity, $\mathrm{NH}_{3}$, EPT (which paralleled invertebrate taxa richness), and $\mathrm{Cd}$ and $\mathrm{Zn}$ concentrations in composite invertebrate samples. Results of MANOVA demonstrated a significant difference between madtom and no madtom sites (Wilks' lambda: $P<0.051 ; N=16$ ). Principal components analyses of the variables used in MANOVA accounted for more than $84 \%$ of the variability in the data with only the first two principal components; the first component effectively separated most Neosho madtom sites from nomadtom sites (Figure 5). Based on the same 16 sites used in MANOVA, invertebrate $\mathrm{Zn}$ concentration was the only significant variable in stepwise discriminant analysis. The resulting discriminant 


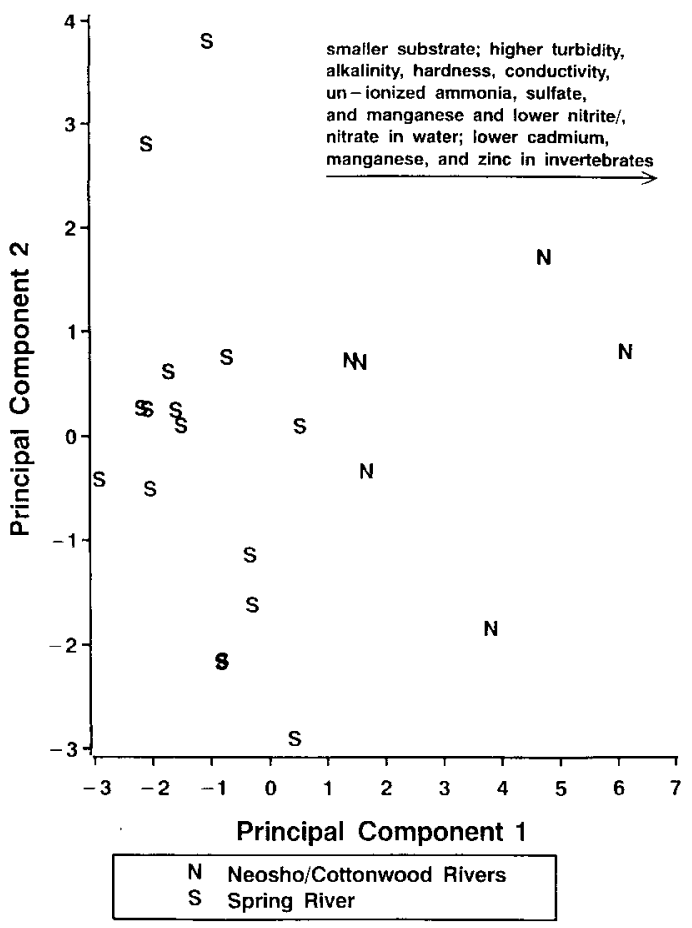

FIGURE 4.-Principal components (PC) analysis of combined Neosho, Cottonwood, and Spring river data based on the shortened list of variables used for MANOVA. For the 22 sites at which all $\mathrm{PC}$ variables were measured, detected, or both, PCl accounted for $43 \%$ of the variability in the data and PC2 accounted for over $19 \%$. Correlations (or loadings) of the variables used for $\mathrm{PC} 1$ were pore-water temperature $(r=0.17, P=0.45)$, turbidity $(r=0.72, P=0.0002)$, alkalinity $(r=0.85$, $P=0.0001)$, hardness $(r=0.82, P=0.0001)$, conductivity $(r=0.71, P=0.0002), \mathrm{NH}_{3}(r=0.78, P=$ $0.0001), \mathrm{NO}_{2}+\mathrm{NO}_{3}(r=-0.69, P=0.0004), \mathrm{SO}_{4}(r$ $=0.61, P=0.0024), \mathrm{Mn}(r=0.60, P=0.003)$; fredle index $(r=-0.50, P=0.017)$; and invertebrate $\mathrm{Cd}(r$ $=-0.67, P=0.0007), \mathrm{Mn}(r=-0.57, P=0.006)$, and $\mathrm{Zn}(r=-0.62, P=0.002)$.

function based on invertebrate $\mathrm{Zn}$ successfully categorized as madtom or no-madtom sites 16 of the 20 Spring River sites (20\% error rate).

\section{Discussion}

Through this study, we have shown that an integrated approach is necessary to differentiate the effects of natural and anthropogenic factors on fish populations and communities. Fishes of the Spring River, especially the Neosho madtom, may be directly limited by the presence of $\mathrm{Pb}, \mathrm{Zn}$, and $\mathrm{Cd}$ in water and indirectly limited by the concentrations of these metals in benthic invertebrate food sources as a result of historic $\mathrm{Pb}-\mathrm{Zn}$ mining. In

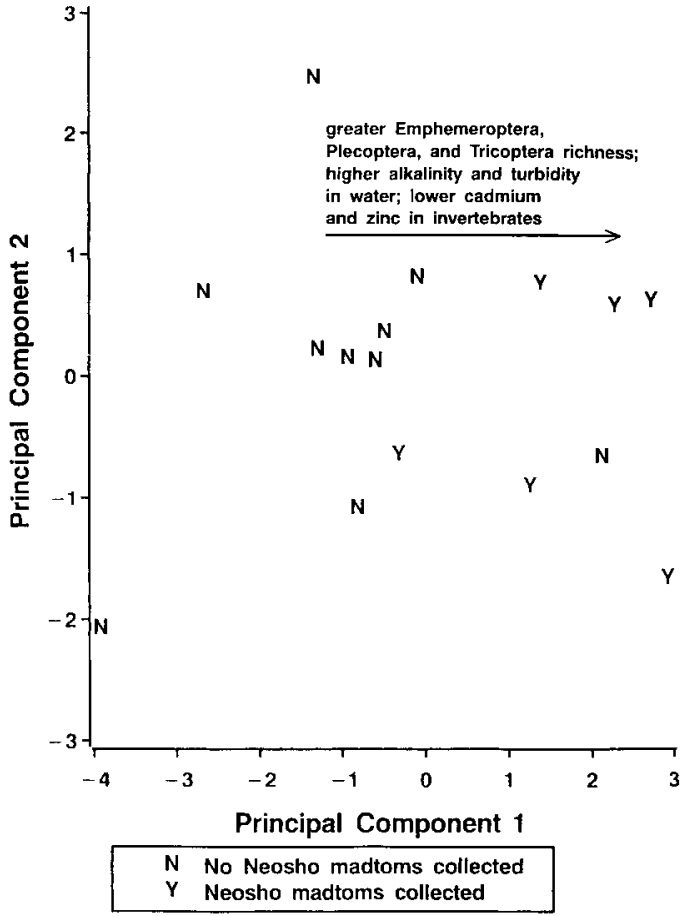

FIGURE 5.-Principal components (PC) analysis of Spring River sites with and without Neosho madtoms based on the shortened list of variables used for MANOVA. For the 16 sites at which all $\mathrm{PC}$ variables were measured, $\mathrm{PCl}$ accounted for $63 \%$ of the variability in the data and $\mathrm{PC} 2$ accounted for $19 \%$. Correlations (or loadings) of the variables used for PC 1 were pore-water turbidity $(r=0.60, P=0.013)$, alkalinity $(r=0.84, P$ $=0.0001)$, and $\mathrm{NH}_{3}(r=0.49, P=0.056)$; EPT $(r=$ $0.92, P=0.0001)$; and invertebrate $\mathrm{Cd}(r=-0.88, P$ $=0.0001)$ and $\mathrm{Zn}(r=-0.95, P=0.0001)$.

the Spring River, Neosho madtom populations may also be directly limited by lower benthic invertebrate abundance (i.e., food) at sites where Neosho madtoms were not collected, possibly as an indirect result of contaminants. The Neosho madtom population numbers also appear limited by available physical habitat, they may be affected by basic water chemistry and nutrients in the Spring River. In contrast, our results suggest that competition between Neosho madtoms and other fishes is not limiting Spring River Neosho madtom populations.

According to estimates from the model generated for the Neosho system and based on habitat and water quality of the Spring River, observed Neosho madtom densities in the Spring River above Center Creek were as expected (i.e., low), whereas below Center Creek observed densities 
were much lower than expected (Figure 3). The Spring River below Center Creek appears to contain habitat that could support Neosho madtom densities higher than was found, on average, in the Neosho system. Thus, Neosho madtom densities in the upper portion of the Spring River appear limited only by habitat, whereas densities below Center Creek appear limited not by physical habitat but by the presence of contaminants. Furthermore, variation in the accuracy of predicted (relative to observed) densities of Neosho madtoms in the Neosho system and Spring River above Center Creek (Figure 3) suggest that other environmental factors not accounted for in the model also affect Neosho madtom densities.

Highest concentrations of $\mathrm{Pb}, \mathrm{Zn}$, and $\mathrm{Cd}$ in the Spring River (all media) occurred below the confluence with Center Creek at sites where Neosho madtoms were not found (Wildhaber et al. 1996, 1997; Schmitt et al. 1997). In pore water, $\mathrm{Pb}$ was never detected and the only detectable $\mathrm{Cd}$ was at the mouth of Turkey Creek. The two highest $\mathrm{Zn}$ levels in pore water occurred at the mouth of Turkey Creek (highest) and at the mouth of Center Creek. Average concentration of $\mathrm{Zn}$ in pore water at the mouth of Center Creek was 1.42 times greater than that of the next highest site. Concentrations of metals in benthic invertebrates paralleled those in water, invertebrates having their highest $\mathrm{Pb}, \mathrm{Zn}$, and $\mathrm{Cd}$ levels at the mouths of Turkey and Center creeks. During 1993, dissolved Zn concentrations in the Spring River just below the confluence with its North Fork were $2.5-80 \mu \mathrm{g} / \mathrm{L}$ during low river flow and 50-80 $\mu \mathrm{g} / \mathrm{L}$ during high flow (Dames and Moore 1993). Dissolved $\mathrm{Pb}$ was never greater than $1 \mu \mathrm{g} / \mathrm{L}$, and $\mathrm{Cd}$ never historically exceeded 0.2 $\mu \mathrm{g} / \mathrm{L}$, but higher concentrations occurred in Turkey, Center, and Short creeks (Dames and Moore, Inc., Denver, Colorado, unpublished data). Although we did not detect either $\mathrm{Pb}$ or $\mathrm{Cd}$ by ICAP, others have documented elevated concentrations of these elements in the Spring River and its tributaries by more sensitive analytical methods. In the Spring River below Baxter Springs, dissolved $\mathrm{Pb}$ averaged $70 \mu \mathrm{g} / \mathrm{L}$ from 1974 to 1978 , and dissolved Cd averaged about $2 \mu \mathrm{g} / \mathrm{L}$. From 1979 to1991, dissolved $\mathrm{Pb}$ averaged $24 \mu \mathrm{g} / \mathrm{L}$ and dissolved $\mathrm{Cd}$ averaged $3 \mu \mathrm{g} / \mathrm{L}$ (Dames and Moore 1993). The dissolved $\mathrm{Zn}$ concentration in Center Creek was $264 \mu \mathrm{g} / \mathrm{L}$ in the summer of 1989 (Schmitt et al. 1993). Zinc concentrations as great as $200,000 \mu \mathrm{g} / \mathrm{L}$ have been reported in Short Creek (Spruill 1987).

Of the mining-derived metals, $\mathrm{Zn}$ concentrations in pore water were sufficiently high to be toxic to Spring River fishes. Based on the USEPA (1987) chronic water quality criteria for $\mathrm{Zn}$, which is hardness-dependent, pore-water concentrations of $\mathrm{Zn}$ exceeded the chronic criterion by $78 \%$ at the mouths of Center and Turkey creeks. Furthermore, because toxicities of heavy metals may be cumulative (Sprague and Ramsay 1965; Wildhaber and Schmitt 1996), concentrations of $\mathrm{Pb}, \mathrm{Zn}$, and $\mathrm{Cd}$ that may not be individually toxic may be cumulatively toxic in the Spring River.

Higher metal concentrations in benthic invertebrates and lower densities of potential competitors at sites where Neosho madtoms were not found suggest that Spring River fishes are exposed to metals indirectly via their food as well as directly via the water. As with waterborne metal concentrations, $\mathrm{Pb}, \mathrm{Zn}$, and $\mathrm{Cd}$ concentrations in benthic invertebrates were greatest at the mouths of Center and Turkey creeks (Wildhaber et al. 1997). Working with laboratory rainbow trout Oncorhynchus mykiss fed a diet containing a mixture of $\mathrm{Pb}$, $\mathrm{Zn}, \mathrm{Cd}$, and copper $(\mathrm{Cu})$, Farag et al. (1994) reported scale loss and accumulation of metals in pyloric caeca, and Woodward et al. (1994) demonstrated reduced growth and tissue accumulation of metals. The concentrations of $\mathrm{Pb}, \mathrm{Zn}$, and $\mathrm{Cd}$ in invertebrates found by Farag et al. (1994) to be detrimental to fish were less than those we observed in benthic invertebrates at the mouth of Center and Turkey creeks; the concentration of $\mathrm{Cu}$ was slightly higher (Table 3 ). The concentrations of $\mathrm{Pb}$ and $\mathrm{Cd}$ in food found to be detrimental to fish by Woodward et al. (1994) were less than those we observed in benthic invertebrates at the mouth of Turkey and Center creeks; the experimental concentrations of $\mathrm{Zn}$ and $\mathrm{Cu}$ were $121 \%$ and $150 \%$ of the concentrations we observed at the mouth of Turkey Creek (Table 3). Other studies have demonstrated detrimental effects of foodborne $\mathrm{Pb}$ (Thomas and Juedes 1992) and Cd (Rhodes et al. 1985). We were not able to measure concentrations of metals in fish and our invertebrate metal analyses were done on taxa that may or may not be food of Neosho madtoms. However, Czarneski (1985) and Schmitt et al. (1993) reported elevated concentrations of $\mathrm{Pb}, \mathrm{Zn}$, and $\mathrm{Cd}$ in black redhorse from Center Creek, and it is therefore likely that other benthic fishes are similarly contaminated. Consequently, our results and those of the studies cited here suggest that dietary metals play a role in constraining the Spring River Neosho madtom population.

In the Spring River, depauperate invertebrate 
TABLE 3.- Concentrations of selected metals in invertebrate food sources from this study, Farag et al. (1994), and Woodward et al. (1994). The concentrations presented for Farag et al. (1994) and Woodward et al. (1994) are the minimum levels at which a detrimental effect on fish was observed. Concentrations are given as $\mu \mathrm{g} / \mathrm{g}$ wet weight (wet) or $\mu g / g$ dry weight (dry).

\begin{tabular}{lccrc}
\hline $\begin{array}{c}\text { Location or study: } \\
\text { measurement type }\end{array}$ & Cadmium & Copper & Lead & Zinc \\
\hline Turkey Creek: wet & 0.72 & 21.20 & 4.22 & 104.29 \\
Turkey Creek: dry & 3.04 & 90.14 & 17.93 & 443.47 \\
Center Creek: wet & 1.15 & 18.77 & 6.06 & 126.85 \\
Center Creek: dry & 4.26 & 69.29 & 22.36 & 468.35 \\
Farag et al. (1994): wet & 0.24 & 26.13 & 1.77 & 68.99 \\
Woodward et al. (1994): dry & 1.20 & 109 & 9.69 & 655 \\
\hline
\end{tabular}

abundance may directly limit riffle-dwelling benthic fishes, including the Neosho madtom. Most of the riffle-dwelling benthic fishes in Spring River feed on benthic invertebrates, including the young, small instars of those used in the EPT index (Pflieger 1975; Mayden et al. 1980; Burr and Mayden 1982; Starnes and Starnes 1985). Our data illustrate the greater numbers of EPT invertebrates at madtom sites than at no-madtom sites (Wildhaber et al. 1996). The similarity in habitat and the differences in contaminant concentrations between madtom and no-madtom sites suggest that observed benthic invertebrate patterns resulted from contaminants. Phipps et al. (1995) demonstrated sensitivity of aquatic invertebrates to waterborne $\mathrm{Pb}, \mathrm{Zn}$, and $\mathrm{Cd}$ with $\mathrm{Zn}$ concentrations only 21 and $35 \%$ of the surface water concentration we observed at the mouths of Turkey and Center creeks, respectively (see Schmitt et al. 1997 for actual values).

Depth, velocity, and substrate are important to Neosho madtoms (Moss 1983; Fuselier and Edds 1994). Our study showed no significant differences in either depth or velocity between river systems or between Spring River madtom and no-madtom sites. However, our study differs from previous investigations in that our analyses are based on overall site means and not microhabitat values, which may vary greatly within a site. The specific substrate composition needs of fishes have been demonstrated by many researchers (Moyle and Vondracek 1985; Wood and Bain 1995) and some studies have focused on threatened and endangered species (Kessler and Thorp 1993; Freeman and Freeman 1994), including other madtoms (Simonson and Neves 1992). Substrate particle size in the Neosho system tended to be smaller than in the Spring River, but there was no difference in particle size distribution between madtom and nomadtom sites within the Spring River (Table 2). Our observation of smaller substrate sizes in the
Neosho system than in the Spring River parallels previous observations of a preference for moderate- to fine-grained substrate by the Neosho madtom (Moss 1983; Fuselier and Edds 1994). The larger average particle size in the Spring River and the significant negative regression coefficient for particle sizes larger than $38 \mathrm{~mm}$ in the model used to predict Neosho madtom densities suggest substrate limitations for the Neosho madtom and other riffle-dwelling benthic fishes in the Spring River, especially above Center Creek. Perhaps the larger interstitial spaces in Spring River gravel do not afford as much protection from predators or as much food for Neosho madtoms as the Neosho system provides, but offers habitat and food for other species such as stonecats.

Basic water chemistry and nutrients differed between river systems; most important are those that differed between madtom and no-madtom sites (alkalinity, $\mathrm{NH}_{3}$, and turbidity). The water chemistry and nutrient patterns we observed in the two river systems parallel those observed by Moss (1983). We know little about the importance of alkalinity and $\mathrm{NH}_{3}$ to Neosho madtoms. The high correlation found among the various water chemistry and nutrient measurements makes any discussion of the importance of alkalinity and $\mathrm{NH}_{3}$ by themselves highly speculative. However, the potential importance of basic water quality to $\mathrm{Ne}$ osho madtoms populations is suggested by the inclusion of $\mathrm{Cl}$, which was highly correlated with conductivity, hardness, and $\mathrm{SO}_{4}$, in the predictive model for Neosho madtom densities and by the significant differences between madtom and nomadtom sites in alkalinity, $\mathrm{NH}_{3}$, and turbidity. Like other prairie stream fishes (Layher et al. 1987), Neosho madtoms seem to prefer higher turbidities. Higher turbidities may afford Neosho madtoms more protection from predators and more opportunity to capture prey with good visual acuity. There was significantly higher turbidity at 
Spring River madtom sites than at no-madtom sites but the difference was minimal compared to the fourfold greater turbidity in the Neosho system than in the Spring River.

Many of the physical habitat, water chemistry, nutrient, and community differences observed between the Neosho system and the Spring River likely are due to the physiographic regions drained. Although the main-stem reaches we sampled in these three rivers are all found in the Prairie Parkland Province ecoregion, the upper reach and many of the tributaries of Spring River drain the very different Ozark Uplands Province (Bailey 1995). This ecoregional effect, which has been documented by others (e.g., Layher and Maughan 1985; Rabeni and Sowa 1996; Leftwich et al. 1997), is an important consideration in understanding how Neosho madtom populations are being affected in the Spring River. The reach of the Spring River supporting Neosho madtoms is the most prairie-like because it is influenced by the North Fork of the Spring River and Cow Creek, which are prairie streams (Figure 1). The Ozark Uplands Province, part of which is drained by some Spring River tributaries and the upper reaches of the main stem, has many spring-fed streams and is composed of limestone that contains large quantities of coarse chert and flint, unconsolidated chert acting as a water filter (Pflieger 1975). More than one-third of Missouri fishes have their distribution centered in the Ozark Uplands (Pflieger 1975). The spring-fed nature, coarse substrate, clear water, and high species diversity of the Ozark Uplands are the likely reasons why Spring River has lower temperature, larger substrate, lower turbidity, and higher fish species rarefaction, respectively, than the Neosho system.

The Neosho and Spring River systems differ substantially in soil types and land use (Moss 1983), differences that are reflected in variables such as conductivity, hardness, alkalinity, $\mathrm{SO}_{4}$, and metals such as $\mathrm{Mn}$. The comparatively high concentrations of dissolved constituents in the Cottonwood River reflect the rocks and soil in its watershed (Hem 1985) and the contribution of the Chase-Council Grove aquifer, the waters of which are characteristically high in $\mathrm{SO}_{4}$ and other ions (Baker and Hansen 1988). Consequently, naturally high $\mathrm{SO}_{4}$ concentrations are typical of the Neosho River system (Kenny and Snethen 1993). In the carbonate-dominated Spring River, some elevation of $\mathrm{SO}_{4}$ occurs from the weathering of pyrite (iron sulfide) in the Pennsylvanian-age shales that overlie the western part of its watershed (Spruill 1987).
In the Tri-State District, ground and surface waters in the Spring River drainage are affected by mining to varying degrees, and $\mathrm{SO}_{4}$ is an indicator of mining-derived water pollution (Barks 1977; Spruill 1987). In these areas, $\mathrm{SO}_{4}$ results from the oxidation of pyrite as well as from the weathering of sulfide ore minerals (sphalerite and galena).

Contrary to what the USFWS (1991) suggested, the observed fish community pattern suggests that interspecific competition is not limiting Neosho madtoms. Fish species richness of Spring River madtom sites was higher than that of no-madtom sites, which is likely due to the lower fish densities at no-madtom sites. After species richness was adjusted for density by rarefaction, there was no difference between Spring River madtom and nomadtom sites. The Spring River did have greater rarefaction than the Neosho system, as expected from descriptions by Cross and Collins (1995). The significant positive correlation between $\mathrm{Ne}$ osho madtom density and potential competitors as a group indicated that Neosho madtom densities increase along with the density of other fishes. If interspecific competition was a primary factor limiting Neosho madtom populations, Neosho madtom densities should have decreased as densities of potential competitors increased. Previous research has supported (Gilliam et al. 1993; Winston 1995) and refuted (Angermeier 1982; Grossman and Freeman 1987) interspecific competition as a determinant of fish community structure. A likely scenario is one of alternating interspecific competition (density-dependent factors) and environmental impacts such as flooding or pollution (density-independent factors) as determinants. Interspecific competition becomes important when density-independent factors are not limiting (Strange et al. 1992); currently, Neosho madtoms seem to be limited by density independent factors such as contaminants and habitat quality. More detailed studies and analyses of interspecific relationships between the Neosho madtom and other species are necessary to further define the role of competition in regulating Neosho madtom populations.

Other factors not measured could affect Neosho madtom populations. We focused on the benthic aquatic communities of gravel bars where Neosho madtom are found and did not attempt to assess communities in pools or other habitats. This decision was based on our primary focus of collecting fishes with similar environmental preferences and the scarcity of Neosho madtoms in any other habitat (Fuselier and Edds 1994). Our focus on riffle-dwelling benthic fish species precluded col- 
lecting any data on fish predators. Predators (i.e., black and temporate basses) in all three rivers are similar (Pflieger 1975; Cross and Collins 1995), but we do not know if predator density differs between rivers. If it does, it could have influenced some of the patterns we have documented.

\section{Conclusions}

When one evaluates limiting factors for rare fishes such as the Neosho madtom, it is important to consider anthropogenic factors as well as physical habitat, basic water chemistry, and nutrients. Knowledge of either low habitat quality or environmental contamination alone does not necessarily lead to effective management decisions that will stop suspected declines of fish populations. Habitat improvement may not improve population status or community composition in a stream if the stream is also heavily contaminated. Conversely, removal of contaminants may also not affect species of concern because physical habitat or basic water quality may be marginal for those populations or communities.

Our results suggest that anthropogenic and natural factors limit Neosho madtom populations in the Spring River. Where metals contamination is minimal, Neosho madtom densities seem to be limited primarily by physical and chemical habitat quality and availability. Where contamination has occurred, Neosho madtoms seem to be limited primarily by the presence of contaminants acting directly (via mortality or avoidance) or indirectly (by suppressing, contaminating, or both the benthic invertebrate food base).

Future research into understanding the population dynamics of the Neosho madtom should include a more detailed look at regional and local factors. A regional factor that may be important to Neosho madtom populations is the regulation of water levels through impoundments on the Neosho and Cottonwood rivers. Local factors include more comprehensive investigations of the effects of microhabitat-scale environmental quality on Neosho madtom distribution across a gravel bar and an evaluation of fish communities, including predators, found in all habitats associated with gravel bars where Neosho madtoms are found.

\section{Acknowledgments}

This study was jointly funded and undertaken by the U.S. Environmental Protection Agency (USEPA), Region 7; the U.S. Geological Survey, through its Columbia Environmental Research Center (CERC); and the USFWS, through its Eco- logical Services (ES) Field Office in Manhattan, Kansas. Assistance with field collections and data processing was provided by A. Bissing, D. Hardesty, P. Heine, P. Lovely, B. Mueller, S. Olson, B. Poulton, B. Scharge, S. Russler, T. Thorn, R. Walton, and D. Whites of CERC; by M. Legg and D. Munie, contracted through USEPA; by C. Charbonneau from USFWS-ES Field Office in Columbia, Missouri; by B. Wilkerson of Oklahoma Department of Wildlife Conservation; and by D. Wright of Missouri Southern State College (MSSC). P. J. Lamberson assisted compiling references and reviewed the initial draft of this manuscript. We thank J. Messick of MSSC for providing laboratory space during the study. We gratefully acknowledge the cooperation of the many private landowners in Kansas, Missouri, and Oklahoma who granted us permission to sample on their properties. This manuscript was greatly improved by comments from D. F. Woodward of the CERC and three anonymous reviewers.

\section{References}

Aadland, L. P. 1993. Stream habitat types: their fish assemblages and relationship to flow. North American Journal of Fisheries Management 13:790-806.

Allen, G. T., and S. H. Blackford. 1995. Contaminants evaluation of Neosho madtom habitats in the Neosho River drainage in Kansas. U.S. Fish and Wildlife Service Contaminants, Region 6 Contaminants Program, Contaminant Report R6/513M/95, Manhattan, Kansas.

Angermeier, P. L. 1982. Resource seasonality and fish diets in an Illinois stream. Environmental Biology of Fishes 7:251-264.

Angermeier, P. L., and J. R. Karr. 1984. Relationships between woody debris and fish habitat in a small warmwater stream. Transactions of the American Fisheries Society 113:716-726.

APHA (American Public Health Association), American Water Works Association, and Water Pollution Environment Federation. 1992. Standard methods for the examination of water and wastewater, 18 th edition. APHA, Washington, D.C.

Bailey, R. G. 1995. Description of the ecoregions of the United States. U.S. Department of Agriculture Miscellaneous Publication 1391.

Baker, C. H., Jr., and C. V. Hansen. 1988. Kansas ground-water quality. U.S. Geological Survey Water-Supply Paper 2325:259-264.

Barks, J. H. 1977. Effects of abandoned lead and zinc mines and tailings piles on water quality in the Joplin area, Missouri. U.S. Geological Survey Water Resources, Investigations 77-75:1-49, Rolla, Missouri.

Bryan, M. D., G. J. Atchison, and M. B. Sandheinrich. 1995. Effects of cadmium on the foraging behavior 
and growth of juvenile bluegill, Lepomis macrochirus. Canadian Journal of Fisheries and Aquatic Sciences 52:1630-1638.

Burr, B. M., and R. L. Mayden. 1982. Life history of the brindled madtom Noturus miurus in Mill Creek, Illinois (Pisces: Ictaluridae). American Midland Naturalist 107:25-41.

Cross, F. B., and J. T. Collins. 1995. Fishes in Kansas, 2nd edition. University Press of Kansas, Lawrence.

Czarneski, J. M. 1985. Accumulation of lead in fish from Missouri streams impacted by lead mining. Bulletin of Environmental Contamination and Toxicology 34:736-745.

Dames and Moore. 1993. Final remedial investigation for Cherokee County, Kansas CERCLA site, Baxter Springs/Treece subsites. Dames and Moore, Inc., Denver.

Eisler, R. 1988. Lead hazards to fish, wildlife, and invertebrates: a synoptic review. U.S. Fish and Wildlife Service Biological Report 85(1.14).

Eisler, R., and R. J. Hennekey. 1977. Acute toxicities of $\mathrm{Cd}^{2+}, \mathrm{Cr}^{6+}, \mathrm{Hg}^{2+}$ and $\mathrm{Zn}^{2+}$ to estuarine macrofauna. Archives of Environmental Contamination and Toxicology 6:315-323.

Farag, A. M., C. J. Boese, D. F. Woodward, and H. L. Bergman. 1994. Physiological changes and tissue metal accumulation in rainbow trout exposed to foodborne and waterborne metals. Environmental Toxicology and Chemistry 13:2021-2029.

Fausch, K. D., and R. J. White. 1981. Competition between brook trout (Salvelinus fontinalis) and brown trout (Salmo trutta) for positions in a Michigan stream. Canadian Journal of Fisheries and Aquatic Sciences 38:1220-1227

Finger, T. R. 1982. Interactive segregation among three species of sculpins (Cottus). Copeia 1982:680-694.

Freeman, B. J., and M. C. Freeman. 1994. Habitat use by an endangered riverine fish and implications for species protection. Ecology of Freshwater Fish 3: 49-58.

Fuselier, L., and D. R. Edds. 1994. Seasonal variation in habitat use by the Neosho madtom (Teleostei: Ictaluridae: Noturus placidus). Southwestern Naturalist 39:217-223.

Gill, T. S., J. C. Pant, and H. Tewari. 1989. Cadmium nephropathy in a freshwater fish, Puntius conchonius Hamilton. Ecotoxicology and Environmental Safety 18:165-172.

Gilliam, J. F., D. F. Fraser, and M. Alkins-Koo. 1993. Structure of a tropical stream fish community: a role for biotic interactions. Ecology 74:1856-1870.

Gorman, O. T., and J. R. Karr. 1978. Habitat structure and stream fish communities. Ecology 59:507-515.

Grossman, G. D., and M. C. Freeman. 1987. Microhabitat use in a stream fish assemblage. Journal of the Zoological Society of London 212:151-176.

Hall, L. W., Jr., M. C. Scott, W. D. Killen, Jr., and R. D. Anderson. 1996. The effects of land-use characteristics and acid sensitivity on the ecological status of Maryland coastal plain streams. Environmental Toxicology and Chemistry 15:384-394.

Hem, J. D. 1985. Study and interpretation of the chem- ical characteristics of natural water, 3rd edition. U.S. Geological Survey Water-Supply Paper 2254.

Hurlbert, S. H. 1971. The non-concept of species diversity: a critique and alternative parameters. Ecology 52:577-586.

James, F. C., and S. Rathbun. 1981. Rarefaction, relative abundance, and diversity of avian communities. Auk 98:785-800.

Johansson-Sjobeck, M. L., and A. Larsson. 1979. Effects of inorganic lead on delta-aminolevulinic acid dehydratase activity and hematological variables in the rainbow trout, Salmo gairdnerii. Archives of Environmental Contamination and Toxicology 8:419_ 431.

Kenny, J. F., and D. H. Snethen. 1993. Kansas stream water quality. U.S. Geological Survey Water-Supply Paper 2400:277-284.

Kerans, B. L., and J. R. Karr. 1994. A benthic index of biotic integrity (B-IBI) for rivers of the Tennessee valley. Ecological Applications 4:768-785.

Kessler, R. K., and J. H. Thorp. 1993. Microhabitat segregation of the threatened spotted darter (Etheostoma maculatum) and closely related orangefin darter (E. bellum). Canadian Journal of Fisheries and Aquatic Sciences 50:1084-1091.

Kiner, L. K., C. Vitello, and K. Hash. 1997. Spring River basin inventory and management plan. Missouri Department of Conservation, Jefferson City.

Layher, W. G., and E. Maughan. 1985. Relations between habitat variables and channel catfish populations in prairie streams. Transactions of the American Fisheries Society 114:771-781.

Layher, W. G., E. Maughan, and W. D. Warde. 1987. Spotted bass habitat suitability related to fish occurrence and biomass and measurements of physiochemical variables. North American Journal of Fisheries Management 7:238-251.

Leftwich, K.N., P. L. Angermeier, and C. A. Dolloff. 1997. Factors influencing behavior and transferability of habitat models for a benthic stream fish. Transactions of the American Fisheries Society 126: 725-734.

Lemaire-Gony, S., P. Lemaire, and A. L. Pulsford. 1995. Effect of cadmium and benzo(a)pyrene on the immune system, gill ATPase and EROD activity of European sea bass Dicentrarchus labrax. Aquatic Toxicology 31:297-313.

Ludwig, J. A., and J. F. Reynolds. 1988. Statistical ecology: a primer on methods and computing. Wiley, New York.

Luttrell, G. R., R. D. Larson, W. J. Stark, N. A. Ashbaugh, A. A. Echelle, and A. V. Zale. 1992. Status and distribution of the Neosho madtom (Noturus placidus) in Oklahoma. Procedures of the Oklahoma Academy of Science 72:5-6.

Maret, T. R., C. T. Robinson, and G. W. Minshall. 1997. Fish assemblages and environmental correlates in least disturbed streams of the upper Snake River basin. Transactions of the American Fisheries Society $126: 200-216$.

Matthews, W. J., and D. C. Heins. 1987. Community 
and evolutionary ecology of North American stream fishes. University of Oklahoma, Norman.

Mayden, R. L., B. M. Burr, and S. L. Dewey. 1980. Aspects of the life history of the Ozark madtom, Noturus albater, in southeastern Missouri (Pisces Ictaluridae). American Midland Naturalist 104: 335-340.

McCormick, F. H., B. H. Hill, L. P. Parrish, and W. T. Willingham. 1994. Mining impacts on fish assemblages in the Eagle and Arkansas rivers, Colorado. Journal of Freshwater Ecology 9:175-179.

McMahon, T. E., A. V. Zale, and D. J. Orth. 1996. Aquatic habitat measurements. Pages 83-120 in B. R. Murphey and D. W. Willis, editors. Fisheries techniques, 2nd edition. American Fisheries Society, Bethesda, Maryland.

Merritt, R. W., and K. W. Cummins. 1984. Introduction to the aquatic insects of North America, 2nd edition. Kendall/Hunt, Dubuque, Iowa.

Milliken, G. G., and D. E. Johnson. 1984. Analysis of messy data, volume 1: designed experiments. Wadsworth, Belmont, California.

Moss, R. E. 1983. Microhabitat selection in Neosho River riffles. Doctoral dissertation. University of Kansas, Lawrence.

Moyle, P. B., and B. Vondracek. 1985. Persistence and structure of the fish assemblage in a small California stream. Ecology 66:1-13.

Neves, R. J., and P. L. Angermeier. 1990. Habitat alteration and its effects on native fishes in the upper Tennessee River system, east-central U.S.A. Journal of Fish Biology 37:45-52.

Omernik, J. M. 1987. Ecoregions of the conterminous United States. Annals of the Association of American Geographers 77:118-125.

Pflieger, W. L. 1975. The fishes of Missouri, 2nd edition. Missouri Department of Conservation, Jefferson City.

Phipps, G. L., V. R. Mattson, and G. T. Ankeley. 1995. Relative sensitivity of three freshwater benthic macroinvertebrates to ten contaminants. Archives of Environmental Contamination and Toxicology 28: 281-286.

Platts, W. S., W. F. Megahan, and G. W. Minshall. 1983. Methods for evaluating stream, riparian, and biotic conditions. U.S. Forest Service General Technical Report INT-138.

Rabeni, C. F, and S. P. Sowa. 1996. Integrating biological realism into habitat restoration and conservation strategies for small streams. Canadian Journal of Fisheries and Aquatic Sciences 53:252-259.

Rhodes, L., and six coauthors. 1985. Interactive effects of cadmium polychlorinated biphenyls, and fuel oil on experimentally exposed English sole (Parophrys vetulus). Canadian Journal of Fisheries and Aquatic Sciences 42:1870-1880.

Roark, S., and K. Brown. 1996. Effects of metal contamination from mine tailings on allozyme distributions of populations of great plains fishes. Environmental Toxicology and Chemistry 15:921927.
SAS Institute. 1990. SAS procedures guide, volume 6, 3rd edition. SAS Institute, Cary, North Carolina.

Schmitt, C. J., M. L. Wildhaber, J. B. Hunn, T. Nash, M. N. Tieger, and B. L. Steadman. 1993. Biomonitoring of lead-contaminated Missouri streams with an assay for erythrocyte d-aminolevulinic acid dehydratase (ALA-D) in fish blood. Archives of Environmental Contamination and Toxicology 25: 464-475.

Schmitt, C. J., M. L. Wildhaber, A. Allert, and B. C. Poulton. 1997. The effects of historic zinc-lead mining and related activities in the tri-states mining district on aquatic ecosystems supporting the $\mathrm{Ne}$ osho madtom, Noturus placidus, in Jasper County, Missouri; Ottawa County, Oklahoma; and Cherokee County, Kansas. Final Report to U.S. Environmental Protection Agency, Region 7, Kansas City, Kansas.

Scott, M. C., and L. W. Hall, Jr. 1997. Fish assemblages as indicators of environmental degradation in Maryland coastal plains streams. Transactions of the American Fisheries Society 126:349-360.

Simonson, T. D., and R. J. Neves. 1992. Habitat suitability and reproductive traits on the orangefin madtom Noturus gilberti (Pisces: Ictalauridae). American Midland Naturalist 127:115-124.

Smith, B. J. 1988. Assessment of water quality in noncoal mining areas of Missouri. U.S. Geological Survey, Water Resources Investigations 87-4286, Rolla, Missouri.

Somero, G. N., P. H. Yancey, T. J. Chow, and C. B. Snyder. 1977. Lead effects on tissue and whole organism respiration of the estuarine teleost fish, Gillichthys mirabilis. Archives of Environmental Contamination and Toxicology 6:349-354.

Sprague, J. B., and B. A. Ramsay. 1965. Lethal levels of mixed copper-zinc solutions for juvenile salmon. Journal of the Fisheries Research Board of Canada 22:425-432.

Spruill, T. B. 1987. Assessment of water resources in lead-zinc mined areas in Cherokee County, Kansas and adjacent areas. U.S. Geological Survey WaterSupply Paper 2268.

Starnes, L. B., and W. C. Starnes. 1985. Ecology and life history of the mountain madtom, Noturus eleutherus (Pisces Ictaluridae). American Midland Naturalist 114:331-341

Strange, E. M., P. B. Moyle, and T. C. Foin. 1992. Interactions between stochastic and deterministic processes in stream fish community assembly. Environmental Biology of Fishes 36:1-15.

Taylor, W. R. 1969. A revision of the catfish genus $\mathrm{No}$ turus Rafinesque, with an analysis of higher vertebrate groups in the Ictaluridae. U.S. National Museum Bulletin 282.

Thomas, P., and M. J. Juedes. 1992. Influence of lead on the glutathione status of Atlantic croaker tissues. Aquatic Toxicology 23:11-30.

USEPA (U.S. Environmental Protection Agency). 1986. Ambient water quality criteria. USEPA, 440/ 5-86-001, Washington, D.C.

USEPA (U.S. Environmental Protection Agency). 1987 
Ambient water quality criteria for: zinc. USEPA, 4405-87-003, Washington, D.C.

USFWS (U.S. Fish and Wildlife Service). 1991. Neosho madtom recovery plan. USFWS, Denver.

Wagner, G. F., and B. A. McKeown. 1982. Changes in plasma insulin and carbohydrate metabolism of zinc-stressed rainbow trout, Salmo gairdneri. Canadian Journal of Zoology 60:2079-2084.

Weber, D. N. 1993. Exposure to sublethal levels of waterborne lead alters reproductive behavior patterns in fathead minnows (Pimephales promelas). NeuroToxicology 14:347-358.

Welsh, B. L. 1951. On comparison of several mean values: an alternate approach. Biometrica 38:330-336.

Wetzel, R. B. 1983. Limnology. Saunders, Philadelphia.

Wildhaber, M. L., and C. J. Schmitt. 1996. Estimating aquatic toxicity as determined through laboratory tests of Great Lakes sediments containing complex mixtures of environmental contaminants. Environmental Monitoring and Assessment 41:255-289.

Wildhaber, M. L., C. J. Schmitt, and A. L. Allert. 1996. Historic zinc-lead mining and related activities and their effects on aquatic ecosystems supporting the Neosho madtom, Noturus placidus, in Jasper County, Missouri; Ottawa County, Oklahoma; and Cherokee County, Kansas. Appendix A: tables A1-A35. Draft Final Report to U.S. Environmental Protection Agency, Region 7, Kansas City, Missouri.

Wildhaber, M. L., C. J. Schmitt, and A. L. Allert. 1997.
Elemental concentrations in benthic invertebrates collected from the Neosho, Cottonwood, and Spring rivers. Final Report to U.S. Fish and Wildlife Service, Region 6, Manhattan, Kansas.

Wilkinson, C., D. Edds, J. Dorlac, M. L. Wildhaber, C. J. Schmitt, and A. Allert. 1996. Neosho madtom distribution and abundance in the Spring River. Southwestern Naturalist 41:78-81.

Winston, M. R. 1995. Co-occurrence of morphologically similar species of stream fishes. American Naturalist 145:527-545.

Wood, B. M., and M. B. Bain. 1995. Morphology and microhabitat use in stream fish. Canadian Journal of Fisheries and Aquatic Sciences 52:1487-1489.

Woodward, D. F., W. G. Brumbaugh, A. J. DeLonay, E. E. Little, and C. E. Smith. 1994. Effects on rainbow trout fry of a metals-contaminated diet of benthic invertebrates from the Clark Fork River, Montana. Transactions of the American Fisheries Society 123: 51-62.

Woodward, D. F., J. N. Goldstein, A. M. Farag, and W. G. Brumbaugh. 1997. Cutthroat trout avoidance of metals conditions characteristic of a mining water site: Coeur d'Alene River, Idaho. Transactions of the American Fisheries Society 126:699-706.

Woodward, D. F, J. A. Hansen, H. L. Bergman, E. E. Little, and A. J. Delonay. 1995. Brown trout avoidance of metals water characteristic of the Clark Fork River, Montana. Canadian Journal of Fisheries and Aquatic Sciences 52:2031-2037. 